\title{
Osmanlı Ekonomi ve Finans Sisteminde Banker Bir Aile: Camondolar ${ }^{*}$
}

Serap BARIȘ' - Uğurcan ÖZEL²

Makale Gönderim Tarihi: 11 1.08.2017

Makale Kabul Tarihi: 08.01.2018

\section{Öz}

Osmanlı İmparatorluğu XVIII. yüzyıldan itibaren sık sık ekonomik ve mali sıkıntılarla karșı karșıya kalmıștır. Art arda gelen savașlar, artan ordu ve saray masrafları nedeniyle mali bunalımlar ve büłçe açıkları süreklilik kazanmıștır. Artan bütçe açıklarını kapatabilmek amacıyla bașvurulan yollardan biri "Galata Bankerleri" olarak bilinen büyük sarraflardan borç almaktı. Borç alınan bu bankerler arasında Camondo ailesi de yer almıștır. Bu çalıșmanın amacı, XIX yüzyılın en etkin bankerlerinden olan Camondo ailesinin Osmanlı Imparatorluğu ile olan finansal ve ekonomik ilișkilerini incelemektir. Calıșmanın sonucu ise Camondo ailesinin sadece finans (bankacılık) alanında değil, kurduğu ișletmeler, verdiği istikrazlar, Osmanlı devlet adamlarıyla siyasi ilișkileri ve bir Yahudi aile olarak bașkent İstanbul'da kazandığı ayrıcalıklar söz konusu dönemde Osmanlı İmparatorluğu'nu ekonomik ve siyasi birçok açıdan etkilemiș olmasıdır.

Anahtar Kelimeler: Camandolar, Galata Bankerleri, Bankacılık, Osmanlı İmparatorluğu.

\footnotetext{
* "Bu çalıșma, Uğurcan Özel'in Gaziosmanpașa Üniversitesi Sosyal Bilimler Enstitüsü'nde 19.04.2017 tarihinde kabul edilmiș olan "Osmanlı Imparatorluğu'nda XIX. Yüzyılda Banker Camondo Ailesi ve Iktisadi Faaliyetleri" isimli yüksek lisans tezine dayanmaktadır."

1 Dr. Öğretim Üyesi, Gaziosmanpașa Üniversitesi, İktisadi ve İdari Bilimler Fakültesi, İktisat Bölümü, Tokat, serap.baris@gop.edu.tr, Orcdi ld: 0000-0003-3905-4746, Bu çalıșma kaynak gösterilerek bașka araștırmacılar tarafından kullanılabilir.

2 İktisat Bilim Uzmanı, ugurcan_ozel@hotmail.com, Orcdi Id: 0000-0003-32573471,
} 


\section{A Banker Family In Ottoman Economy and Finance System: Camondos}

\section{Abstract}

Since the XVIII century, the Ottoman Empire has often faced economic and financial difficulties. Due to the wars that followed, the increasing army and the cost of the palace, financial crises have become permanent. One of the ways in which they resorted to borrowing money from major currencies, known as "Galata Bankers", in order to close up the increased budget deficits. Among these borrowed bankers was the Camondo family. The purpose of this study is to examine the financial and economic relations of the Camondo family, one of the most influential bankers of the XIX century, with the Ottoman Empire. The end result of the study is that the Camondo family influenced the Ottoman Empire in many economic and political terms not only in the finance (banking) area, but also in the establishments, the loans, the political relations with the Ottoman statesmen and the privileges granted in the capital Istanbul as a Jewish family.

Keywords: Camondo's, Galata Bankers, Banking, Ottoman Empire.

\section{Giriș}

Banker terimi, banka teriminin kökeni gibi İtalyancadan türemiștir. Özellikle Ortaçağ'da sarraflar ticaret bölgelerinde paraları tartmak, bozmak ve değiștirmek ișlemlerini yapmaktaydılar. Sarraflar bu ișlemleri yaparken bankta oturduklarından dolayı da "banker" adını almıșlardır. Sonraki yıllarda kelimenin kullanımı değișiklik göstermiștir. Batı'da banker sözcüğü, banka sahibi veya bankacı anlamlarında kullanılmaktadır (Oğlakçı, 2007: 53-59). Ancak Osmanlı İmparatorluğu döneminde banker terimi, büyük sermaye sahibi olup bankası olmayan kișiler için de kullanılmıștır.

Galata'da yerleșik olup, özellikle XIX. yüzyılın ikinci yarısında bankerlik ișletmelerini kuran çoğunluğu gayrimüslim olan sarraflar/bankerler/bezirgânlar İstanbul'da Bizans döneminden itibaren para, alıın, kıymetli maden ișleriyle uğrașan, faizle para 
veren tefecilerin uzantıları sayılabilir. Bunların temel ișlevi, Batı Avrupa'da gerçekleșen sanayi devrimi sonrasında, Osmanlı İmparatorluğu ile Batı sermaye çevreleri arasındaki ilișkiyi sağlamak olmuștur (Çetin, 2009: 60). Galata bölgesinde yerleșik olup, faaliyetlerini o bölgeden yaptıklarından "Galata Bankerleri" olarak adlandırılan bankerler, bașlangıçta hem Osmanlı́nın iç borçlanma ihtiyacını hem de dıș ticaretin kredili alım-satım ișlemlerini karșılașmıșlardır (Kazgan, 1995: 92). Sonraki dönemlerde ise devlete borç vermenin de ötesinde Osmanlı İmparatorluğu'nun kısa vadeli dıș borçlanmasına aracılık yapmıșlardır. Yabancı sermayeli bankaların kurulmasına ve yabancı bankaların imparatorluk içinde șube açmaya bașladıkları zamana kadar bankacılık faaliyetlerini yerine getirmișlerdir.

Galata Bankerlerinin önde gelenleri arasında Baltazziler, George Tubini, Lorando, Bernard Corpi, Zanni Stefanovich, Shilizzi, Glavani, Raoul Crespin, Eustache Evyenidis, Camondolar, Fernandez, George Zarifi, Mavrokordato, Yorgo Zafiropula, Christaki Zografos, Jacques Alléon, Mısırlığlu Bogos Bey ve Köçeoğlu Agop (Manav, 2009: 9-13) yer almaktadır.

Dönemin önemli bankerlerinden olan Camondolar'ın kökeni İspanya'ya dayanmaktadır. 1492 yılında Katolik kral ve kraliçenin Müslüman ve Musevilerin İspanya'yı terk etmesine yönelik verdikleri karar, Camondolar'ın ataları için de yeni bir bașlangıç olmuștur. İspanyol kökenli Yahudiler anlamına gelen Sefaradlar önceleri Navarra, Portekiz ve İtalya'ya yönelmișler, sonra da Marranolar'la bulușmușlardır. Ancak iki parçaya bölünmüșler, azınlık bir grup Kuzey Afrika'yı seçerken, çoğunluğu da İtalya'dan geçerek Osmanlı İmparatorluğu'nu tercih etmișlerdir (Assouline, 1998: 64). Bu konuda kesin bilgiler vermek güç olmakla birlikte, İspanya'dan İtalya'ya Venedik'e gelip yerleștikleri, oradan da XVII. yüzyıl ortalarında İstanbul'a geldikleri bilinmektedir (lipek, 2011 : 8). Orjinal yazılıș biçimiyle Camondo sözcüğünün kökeni Fransız tarihçi Philippe Erlanger'e göre Venedik lehçesinde "Dünya Evi" anlamına gelen Ca'Mondo'dur. Bu konudaki diğer bir kanıt ise, Venedik çevresinde bu isimle tanınan küçük bir Yahudi cemaatinin varlığıdır (Güleryüz, 2015: 404). 
Ailenin İstanbul'da varlığı tespit edilen ilk üyesi Haim Camondo'dur" ${ }^{3}$. Haim İngiltere, Fransa ve Avusturya'dan "beratlı tüccar"4 sıfatına sahip bir tüccardır (Șeni ve Tarnec, 2010: 12). 1782 yılında tam olarak bilinmeyen bir sebepten dolayı, Osmanlı padișahı tarafından ülkeyi terk etmesi için kendisine 24 saat süre tanındığında, Haim Camondo ailesi ile birlikte Trieste'ye gitmiștir (Ípek, 201 1: 162). Bu tarihten iki yıl sonra (1784) Baron Rathkeal'in çabaları sonucunda Haim'in oğlu Abraham, İstanbul'a dönerek ailenin ișinin bașına geçme izni almıș ve ailenin İstanbul'da mal varlığına el konulmamıș olması nedeniyle de pek zor bir durumla karșılașmamıștır (Șeni ve Tarnec, 2010: 13).

1802'de Isaac (?-1832) ve Abraham-Salomon Camondo (1780/85-1873) kardeșler tarafından hayata geçirilen Isaac Camondo \& Cie. (Isaac Camondo ve Șürekası) adlı banka, kısa zamanda büyük bir gelișme göstererek önemli bir global șirket haline gelmiștir. 5 Eylül 1832'de ağabeyi Isaac Camondo'nun vebadan ölümüyle kendisine miras kalan 25 Milyon Dolar tutarında bir servetin sahibi olarak șirketin bașına geçen Abraham-Salomon Camondo, șirketin yönetimini eline almıș ve 30 yıl boyunca bu yetkiyi kimseyle paylașmayarak șirkete büyük bir atılım yașatmıștır (Tugay ve Tugay, 2009: 47). Abraham Salomon Camondo, Camondo Ailesi'ni, hem mali yönden hem gayrimenkul yönünden zenginleștirerek, yönetmeye bașlamıștır. Aile, Kırım Savașı sırasında savunma gereksinimleri ve sonrasında vergiler, gümrükler ve tekeller garantisiyle Osmanlı İmparatorluğu'nun bankerliğini yaparak daha da zenginleșmiștir. Camondolar Baron Hirsch ve Tanzimat hareketinin en önemli ismi durumundaki Mustafa Reșit Pașa gibi önemli kișilere de sarraflık yapmıștır. Abraham Salomon Camondo hem Sultan Abdülmecid'in hem de Sultan Abdülaziz' in yönetiminde önemli bir nüfuza sahip olmuștur (Demirkaya, 2010: 18).

1860'lı yıllarda bașkent İstanbul'da ortaya çıkmaya bașlayan Rum Bankerlerin kurdukları yeni banka ve șirketler nedeniyle

\footnotetext{
3 Ailenin soy ağacı için bakınız Ek-1.

4 XVIII. yüzyıldan itibaren gayrimüslim Osmanlı tebaasından Avrupa devletlerinin himayesine girerek müste'min tüccar gibi iç ve dıș ticarette, imtiyazlı bir șekilde ticaret yapan kimselere "beratlı tüccar" denilmektedir (Bağıș, 1983: 17).
} 
Camondo Ailesi 1869 yılında Paris'e göç etmiștir. Avrupa ortaklı bu yeni ișletmelerin Camondo'nun İstanbul'daki prestijini önemli ölçüde sarstığı görülmektedir. Bu doğrultuda Camondolar'ın yeni planı ise dünyanın en önemli finansal merkezlerinden biri olan Paris'e yerleșmek, Avrupa ve Paris'in ünlü bankerleriyle birlikte çalıșip is yaparak, yerlerini almaya bașlayan Rum bankerlerle rekabette büyük ölçüde avantaj sağlamakłır (İpek, 201 1: 164).

Paris'e yerleșen Camondo Ailesi'nin bir ayağı bu nedenle daima İstanbul'da kalmaya devam etmiștir. Șirketle birlikte büyük miktardaki mal varlığı, hanlar, arsalar, evler, apartmanlar İstanbul'da Camondolar'ın bugün kalan izleri olarak günümüzde de görülebilmektedir. Bundan sonra bir yandan Paris'in ekonomik ve sosyal dünyası içine yerleșmeye çalıșan Camondolar, diğer taraftan da İstanbul'daki șirketin idaresini ve yeni yatırımlarını Paris'le İstanbul arasında gidip gelen mektuplarla sağlamaya çalıșmıșlarsa da bu durum zamanla İstanbul aleyhine bozulmuștur. Abraham ve Nissim'in ölümünden sonra ise ağırlık bütünüyle Paris'e kaymıștır. Sonraki yıllarda Camondolar'ın çocukları (Isaac ve Moise) bankerlik ve finans konusunda pek de hevesli davranmamıșlardır. Bunun bir sonucu olarak 1894 yılında Camondo Bankası'nın ișleri tasfiye edilmiș, șirketin bundan sonra yalnızca mülklerin idaresi ile ilgilenmeye devam etmesi kararı alınmıștır (ipek, 2011: 164-166). Bir yüzyıldan fazla bir süreye büyük bir șöhret ve servet sığdırmıș olan Camondo Ailesi'nin Osmanlı Imparatorluğu ile olan iktisadi ilișkileri ve günümüze kadar ayakta kalan eserleri dikkate değerdir. Bu çalıșma ile Camondo ailesinin Osmanlı İmparatorluğu ile olan finansal ve ekonomik ilișkilerinin niteliği ve boyutunun incelenmesi amaçlanmıștır. Bu amaçla öncelikle ailenin Osmanlı ile olan finans ve bankacılık alanındaki faaliyetleri ele alınmıș, ardından ticari ve ekonomik faaliyetleri incelenmiștir.

\section{Camondo Ailesi'nin Osmanlı İmparatorluğu'ndaki iktisadi Faaliyetleri}

Camondo Ailesi'nin Osmanlı İmparatorluğu ve bürokratlarıyla yakın ilișkiler içinde olduğu bilinmektedir. Osmanlı devlet adamları ile Camondolar'ın bağlantısı iki șekilde olmuștur. Bunlardan 
biri Camondo Bankası ve devlet arasındaki resmi ekonomik ilișkiler șeklinde, ikincisi de sarraf veya banker kimliği ile Camondolar'ın bürokratlarla kișisel olarak kurdukları ilișkiler șeklinde kendini göstermiștir. Camondolar İstanbul'da bulundukları süre içerisinde dört padișah (Abdülmecid, Abdülaziz, V. Murad, II. Abdülhamid) dönemi yașamıșlardır. Devletle olan ilișkileri, birçok ayrıcalığı da beraberinde getirmiș ve ailenin zenginleșmesinde büyük rol oynamıștır. Osmanlı İmparatorluğu'nun Camondolar'a ayrıcalık tanımasının sebebi kısa vadeli sıcak para ihtiyaçlarını sorunsuz olarak karșilama arzusudur.

Osmanlı İmparatorluğu'nda XIX. yüzyılın önemli siyasi gelișmelerinden olan Tanzimat ve Islahat Fermanlarının yaratttğı süreçte en çok gayrimüslimleri ilgilendiren reform hareketleri Camondolar'ın ve Yahudi cemaatinin büyük finans destekleri almasına yol açmıștır. Tanzimat Döneminin önemli isimleri olan Mustafa Reșid, Âli ve Fuad Pașalar ile Camondolar arasında bir yakınlık söz konusudur. Özellikle büyük baba Abraham Camondo'nun Reșid Pașa'nın hem çok yakın dostu hem de özel sarrafı olduğu Camondolar'la ilgili yazılmıș tüm kaynaklarda belirtilmektedir.

Sarraf Abraham Camondo, Fuad Pașa'nın da özel sarraflığını yapmıștır. Akșam Gazetesi'nin 10 Aralık 1934 tarihli nüshasında Süleyman Kani İrtem tarafından kaleme alınmıș olan "Eski Vezir ve Sarraf" bașlıklı yazıda, bu ilișkinin rakamsal ifadelerine yer verilmiștir. 1865 yılında Ticaret ve Nafia bakanı olan Kabuli Pașa'nın arșivinde yer alan beș adet tahvil, Fuad Pașa'nın Camondo'dan almıș olduğu yüklü miktardaki borçları göstermektedir. 1855 tarihini tașıyan ilk tahvilde 23.181 Kuruș ve aynı tarihi tașıyan ikincisinde de 30.000 Kurușluk kredi hesapları yer almaktadır. Illk tahvildeki kredi faizsiz olmakla birlikte, ikincisinde, bir kese 500 Kuruș hesabıyla, kese bașına 5 Kuruș faiz belirlenmiștir. 30 Mart 1860 tarihli üçüncü tahvilde rakam ve buna bağlı olarak faiz oranı da yükselmiș, 50.000 Kurușluk kredi için \% 12 faiz hesabı yapılmıștır. Dördüncü ve beșinci tahvillerde ise kredi limiti daha da yükselmiștir. Ocak 1859 'da Camondo'dan alınan tutar 83.624 Kuruș iken, Ekim 1859'da 150.000 Kurușa kadar çıkmıșıı (lipek, 2011: 168). 
Camondolar'ın devlet adamları ve bürokratlarla özel ilișkileri sonucunda geliștirdikleri sermayeleri, Osmanlı İmparatorluğu'nda kurulacak olan birçok ișletmenin finansmanın sağlanmasında önemli rol oynamıștır. Camondo Ailesi'nin Osmanlı İmparatorluğu'ndaki ilk iktisadi faaliyetleri bankacılık alanında olmuștur.

\subsection{Bankacilık Sektörü}

Osmanlı İmparatorluğu'nda modern bankacılığın gelișimi farklı nedenlere dayanır. Tarıma dayalı bir ekonomik yapı, iç isyanlar, uzun süren ve kayıplarla neticelenen savașlar, artan saray ve ordu masrafları neticesinde devlet bütçesinin açık vermesi bu nedenlerin en önemlilerindendir. Osmanlı yönetimi bu bütçe açıklarını kapatmak amacıyla kağı para basımının yanı sıra dıș borçlanmaya da bașvurmak zorunda kalmıștır. Bașlangıçta kaime basılarak karșılanmaya çalıșılan masraflar Kırım Savașı́nın bitiminde 1854 yilında ilk dıș borçlanmaya kadar götürmüștür.

Galata bankerleri ile Avrupa sermayedar ve bankerleri arasındaki ilișkiler, 1854 yılından sonra daha da pekiștirilmiștir. Bu tarihten 1881 Düyun-u Umumiye'nin kurulușuna kadar geçen süren dönem Osmanlı için bir "istikraz fırtınası" dönemi olmuștur. Yerli ve yabancı bankerlerin borç alınmasını teșvik etmeleri, borçların veriliș șartları ve kullanım biçimleri, bunların çığ gibi büyümesine neden olurken bu süreç aynı zamanda Osmanlı Imparatorluğu'nda yabancı bankacılığın ortaya çıkmasına yol açmıștır (Silier, 1975: 487). Yabancı bankerlerin girișimleri yanında Osmanlı devlet yönetimi de bir bankaya olan ihtiyacı ortaya koyunca Türk bankacılık literatüründe ilk banka olarak kabul edilen Dersaadet Bankası (Banque de Constantinople) kurulmuștur. Bankanın kuruluș tarihi konusunda çeșitli tarihler zikredilmekle birlikte 1849 yılı ortalarında kurulmuș olması kuvvetle muhtemeldir. Banka sermayesinin \%40'ı devlet, \%60' ı ise Galata bankerlerinden Alléon ve Baltazzi tarafından karșılanmıștır. Bankanın kurulmasındaki temel amaç kaime fiyatlarındaki așırı dalgalanmaların önüne geçerek istikrar sağlamaktır. Bu amaçla birlikte Banka kambiyo istikrarı uygulamasını da sürdürmüștür (Al, Akar ve Bayraktar, 2014: 63-65). Dersaadet Bankası ödeme gücünü tehlikeye düșüren faaliyetlere 
bașvurması ve spekülasyon yapması nedeniyle 1852 yılında tasfiye edilmiștir. Bu tarihten sonra da Osmanlı İmparatorluğu'nda bankacılık arayıșları devam etmiștir. Özellikle bu dönemde İngiliz sermayesi kanalıyla borçlanan devlet, bunun etkisiyle bir İngiliz girișimi olan Bank-ı Osmani'nin kurulmasına izin vermiștir. 1856 yılında kurulan Bank-ı Osmani'ye Fransız sermayesi de katılarak -1863 yılında- o günkü adıyla Bank-ı Osmani-i Șahane (Osmanlı Bankası) olmuștur (Erdoğan, 1993: 487). Bu banka Türkiye Cumhuriyet Merkez Bankası kuruluncaya kadar emisyon yaratma yetkisine sahip olarak faaliyet göstermiștir. İmparatorluk içinde uzunca bir süre Merkez Bankası fonksiyonunu bir yabancı bankanın görmesi, Osmanlı ekonomisi için yabancı bankacılığın önemini göstermektedir. Osmanlı Bankası'nın kurulmasından sonra da çok sayıda yabancı banka faaliyete geçmiștir.

\subsubsection{Isaac Camondo Bankası}

1815 yilında Abraham Camondo ve ağabeyi Isaac Camondo tarafından kurulan Isaac Camondo ve Șürekası Bankası Osmanlı'nın 1830'lardan itibaren birçok finansman ihtiyacını karșılamıș, aynı zamanda Avrupa merkezli bankalardan alınan kredi ve borçlanmalarda da etkin bir rol oynamıștır. Viyana Borsası, Paris ve Londra iș çevreleri ve bankalarıyla yoğun bir münasebeti olan söz konusu banka, birçok yabancı bankanın Osmanlı İmparatorluğu muhabiri idi. Söz konusu banka aynı zamanda Baron Hirsch gibi ünlü zenginlerin İstanbul bankerliğini de yapmıștır (Güleryüz, 1994: 404).

Abraham Camondo, Osmanlı İmparatorluğu'nda gayrimenkul edinme izni alan ilk yabancıdır (Güleryüz, 1994: 404). Gayrimüslim olması sebebiyle sahibi olduğu banka, verilen borca karșı güvence olarak ipotek gösterilen ve el konulan gayrimenkullere karșilık, borçlular taahhütlerini yerine getiremedikleri zaman șirket borçluların taahhüt gösterdikleri gayrimenkullere doğrudan sahip olamamaktaydı fakat ilerleyen süreçte padișah iradesiyle Abraham Salomon Camondo'ya "bașkalarına emsal teșkil etmemek kaydıyla" gayrimenkul edinme hakkı verilmiștir (Tugay ve Tugay, 2009: 276). 
XIX. yüzyılın ortalarından itibaren sayıları artmaya bașlayan yeni bankaların ve bu arada Osmanlı Bankası́nın kurulması ile Isaac Camondo ve Șürekası Bankası eski itibarını kaybetmeye bașlayarak yerlerini Ermeni-Rum bankerlere bırakmıșlardır. Oysaki söz konusu banka, Kırım Savașı (1853-1856) esnasında Osmanlı İmparatorluğu'nun savunma ihtiyaçlarını karșılayan banka konumundadır (Güleryüz, 1994: 404-405). Avrupa ile kurulan yeni ilișkilerin sonucunda olușturulan yeni finans șirketleri, Camondo Ailesinin Osmanlı İmparatorluğu'ndaki ișlerinin aksamasına neden olmuș ve ailenin 1869 yılında Paris'e göç etme kararı almasının önünü açmıștır. Ancak Paris'e yerleșme kararının alındığı bir zamanda, Süveyș Kanalı'nın açılıșı için Mısır'a gidecek olan İmparatoriçe Eugenie'nin Osmanlı topraklarında kendisine hizmet vermek üzere Camondo Bankası'nı seçmiș olması Banka'nın itibarını yeniden artırmıștır. Bu olay Isaac Camondo ve Șürekası Bankası'nın son kârlı iși olmuștur. 1869'da Paris'e göç nedeniyle İstanbul'daki ișlerinin bașına vekâleten Moise Fernandez geçmiștir. İșlerin uzaktan yönetim ve idaresinin zor olması ve diğer bazı olumsuzluklar nedeniyle, Abraham Behor Camondo'nun oğlu Isaac 1894'de almıș olduğu kararla bankayı tasfiye etmiș, bankadaki hesapları Banque de Change et de Valeurs'e devretmiștir. Gayrimenkul ișlerinin sürdürülebilmesi için șirketin devamı sağlanmıș ancak 1917 yılında Isaac Camondo ve Șürekâsı Șirketi tamamen kapatılmıștır (Șeni ve Tarnec, 2010: 117-119).

XIX. yüzyılın ikinci yarısında banka kurma girișimlerinin sayısı artmıș ve 1856'da Bank-ı Osmani kurulmuștur. Dersaadet Bankası ile aynı amaçları tașıyan bu banka 200.000.000 Kuruș sermaye ile faaliyete geçmiș ancak Kırım Savașı'nın bașlaması ve hükümetin kredi isteğinin kısa sürede sağlanamaması nedeniyle bu bankanın da finans yașamı kısa sürmüștür. Bu dönemde Todoraki Baltacı ve Camondo Osmanlı İmparatorluğu'na yeni bir banka kurulması teklifinde bulunmușlardır. Sunulan bu yeni teklife göre; 60.000 kesesi Saltanat- Seniyye tarafından ve 340.000 kesesi hisse sahipleri tarafından karșılanmak üzere toplam 400.000 keselik bir sermaye belirlenmiștir. Yeni kurulacak olan bu banka her türlü kâr ve zararı kendi üzerine almayı, devlet tarafından bir ücret ve masraf ödenmemek üzere, kambiyoyu İngiliz Sterlini 
karșısında 110 Kurușta tutmayı ve piyasadaki kaimeleri nakitle değiștirmeyi taahhüt etmektedir. Buna karșılık devlet tarafından imtiyaz süresi olan 12 yıl boyunca bankaya her yıl 76.000 kese, yani toplam 912.000 kese Akçe ödenecektir. Bu tutar aracılığıyla banka bir veya iki yıl içinde bütün 5'lik ve 6'lıklar ile beraber 20 ve 10 paralık akçeleri tedavülden kaldırarak yerine piyasaya 20'lik ve 100'lük Mecidiye Sikkesi sürecektir (İpek, 2011: 173). Fakat bu teklif Osmanlı İmparatorluğu tarafından kabul görmeyerek onaylanmamıștır.

\subsection{2. Șirket-i Maliyye}

Osmanlı İmparatorluğu'nun mali sıkıntılarının arttığı bir dönemde Abraham Camondo, George Zarifi, Aristidi Baltacı ve Tubini bankerler tarafından 320.000 Sterlin sermayeyle, kambiyo üzerinden ișlem yapmak üzere Șirket-i Maliyye adlı bir banka kurulmuștur. "Ittihad-ı Maliye" adıyla bilinen İttihad-ı Mali/Șirket-i Maliyye (Union Financiére) adlı șirketin 5.000 Sterlinlik 64 hisseden olușan 320.000 Sterlinlik sermayesinin 28 hissesi hissedar Tubini ve Corpi'ye, kalan 36 hissesi ise eșit olarak Baltazzi, Zarifi ve Camondo'ya aittir (Çetin, 2009: 123).

20 Kasım 1859 tarihinde imzalanan anlașmayla 10 yıllık bir süreç içinde Londra'da üç ay vadeli poliçeler çekmek șartıyla Sterlini 110 Kurușa sabitlemeyi kabul etmiș ve Osmanlı Imparatorluğu'nun Avrupa ile yaptığı alıșverișlerde sikkenin fiyat farkı nedeniyle uğradığı zarardan bir bakıma kurtarıımasının sağlanması amaçlanmıștır (lipek, 2011 : 178). Șirket, hükümet taahhüdünü gereği gibi yerine getirememiș, gerekli tahsilatı sağlayamamıș ve düzen poliçeleri düzenleme görevini yerine getirememiștir. Vadesi gelen poliçeler üzerinden yapılan borcun vadesini uzatma ișlemi sonucunda, Avrupalı sermayedarların bu poliçeleri kabul etmemesi üzerine proje olumsuz neticelenmiștir (Akyıldız, 2003: 104-108).

Sonuç olarak bakıldığında, șirketin kısa sürede faaliyetlerine son vermek zorunda kalmasının en önemli nedeni, kurucu bankerlerin daha fazla kazanmak amacıyla yaptığı spekülasyonlar olmuștur. Avrupa üzerine çektikleri poliçelerin karșılığını gönderme- 
meleri Avrupa piyasalarında itibar kaybı yaratırken, Avrupa'dan \% 4-5 faizle aldıkları paraları \% 12 faizle hükümete borç vermeleri de iç piyasadaki itibarlarını sarsmıștır (lpek, 2011 : 178). Kaime ancak, Deveaux\&Co. Sirketi'nden alınan \% 6 faizli 8 Milyon Sterlin dıș borç ile tedavülden çekilebilmiștir. Alınan bu istikraza merkez bankası ișlevi gören Bank-ı Osman-i Șahane aracılık etmiștir. Tahviller \% 68 ihraç fiyatıyla satılmıș ve kaimeyi tedavülden kaldırmak için gerekli finansmanın sağlanmasıyla 1862 Haziran'ında ikinci așamaya geçilmiștir. Kaime bedellerinin tamamının madeni parayla ödenmesi, Devlete büyük bir mali yük getireceğinden \% 40'ı nakit, \% 60'ı ise esham verilerek ödenmiști. Böylelikle kaimeler 1862 Eylül'ünde tedavülden çekilebilmiștir (Hulkiender, 2003: 124).

\subsection{3. Șirket-i Umumiyye-i Osmani}

Osmanlı İmparatorluğu'nun mali buhranlarla birlikte borçlanma ve bankacılık konusunda yașadığı olumsuz deneyimler bir devlet bankasına olan ihtiyacı ortaya çıkarmıștır. Özellikle dıș borç bulma konusunda Avrupa piyasalarının sıkıntı yașayan devletin piyasaların güveninin yeniden kazanmak için bir bankanın garantörlüğüne de ihtiyacı vardır (lipek, 2011: 179). Bunun sonucunda 4 Șubat 1863 tarihinde Fransız ve İngilizlerin girișimiyle ilk uzun süreli devlet bankası olan Bank-ı Osmani-i Șahane kurulmuștur (Bayraktar, 2002: 79). Yaklașık bir yıl sonra Șirket-i Umumiyye-i Osmanî (Société Générale de l'Empire Ottoman) kurulmuș ve kurulușa Bank-ı Osmanî de iștirak etmiștir. Șirketin kurucuları Aristide Baltazzi, Bischoffsheim Goldschmidt et Cie, J. Camondo et Cie, Mısırlıoğlu Bogos Bey, Oppenheim Alberti et Cie., A. A. Ralli, Z. Stéfanovich, Stern, S. Sulzbach, Zafiropoulo et Zarifi, Christaki Zografos idi. Șirket, öncelikle kısa vadeli istikrazlara aracılık edecek ve katılacak, her türlü mali ve ticari ișle uğrașabilecekti. Șirket-i Umumiyye'nin, 2.000.000 Sterlinlik sermayesi 20 Sterlin itibari değerde 100.000 hisseden oluștu. Hisse senetlerinin 13.000'i Bank-ı Osmanî, 67.000'i ise kurucular tarafından alındı. Kalan hisselerin 6.500'ü İstanbul'da, 26.500'ü de Londra'da halka arz edildi. Satıșa sunulan hisseler hızla tükendi; talep 220.000'i aștı. Șirket-i Umumiyye, yüksek itibari sayesinde henüz kuruldu- 
ğu 1864 yılı sonunda hükümetle 50.000.000 Franklık bir istikraz anlașması imzalayabilecek duruma gelmiș ve kapılarını kapattı̆̆ı tarihe kadar kurucularına çok büyük kazançlar sağlamıștır. Șirketin merkezi Camondo Han'da bulunmaktaydı. Bank-ı Osmanî ve Șirket-i Umumiyye hükümete borç vermeye bașlamıștı ama hazinenin kısa ve orta vadeli nakit açıkları için aynı zamanda Galata Bankerlerinden de borçlanma devam ediyordu. Dairelerin Nisan ayı tahsisatlarından eksik kalan tutarlar ile Mayıs ayı tahsisatı, dıș borç taksitleri gibi bazı masraflar için Mısırlığlu Bogos Zografos, Camondo, Zarifi ve Stefanovich'ten \%10 faiz ve \%2 komisyonla 250.000 liralık istikraz yapılmıștır (Manav, 2009: 164,165).

1870 yılına kadar Osmanlı İmparatorluğu'na büyük miktarda borç veren Banka, 1866'dan sonra Osmanlı tahvillerinin Avrupa piyasasında değer kaybetmesinden büyük ölçüde etkilenmiș ve sahip olduğu hisseler 1866 'dan sonra nominal değerlerinin üstünde prim yapmamıșıır. Bu bankanın yaptığı ișlere Galata ve Azapkapı Köprülerinin gelirleri karșılığı Bahriye Nezareti'ne \% 18 faizli 400.000 Liralık kredi açmaları örnek gösterilebilir (Kazgan, 2014: 121). 1869 yilında Paris'e yerleșen Camondolar'ın șirketle bağlantısı sekteye uğramıștır. Ayrıca 1868 yılında Credit General Ottoman Bankası'nın kurulması Șirket-i Umumiye'nin etkinliğini azaltmıștır. Societe General de France grubu ile İstanbul'da Galata Bankerlerinden Tubini ve firmasının birleșmesiyle olușturulan bu bankanın sermayesi 50.000.000 Frank olarak belirlenmiștir. Credit General Ottoman'ın kurulușu, Șirket-i Umumi'nin büyük hissedarları tarafından yapılmıștır. Camondolar'ın bu ortaklıktan dıșlanması Credit General Ottoman'ın rekabetinin tamamen Camondolar'la olduğu olgusunu ortaya çıkarmaktadır. Camondolar'ın yașadığı itibar kaybı, aile için 1869 yılında Paris'e yerleșme fikrini gündeme getirmiștir. Comptoire National d'Escompte de Paris Șirketi'nin Osmanlı İmparatorluğu'yla istikraz anlașması yapması ve Camondolar'ın girișimleri sonucu kontratın bir kısmını Șirket-i Umumiye devretmesi Camondolar'ın bu istikrazdan payını almasını sağlamıșıı (İpek, 2011 : 185).

Credit General Ottoman kurulușuyla dıșlanan ve tek rakip konumuna getirilen Camondo Ailesi 1870'lerden itibaren İstanbul 
ve Galata üzerindeki etkinliğini kaybetmișlerdir. Șirket-i Umumi Osmani 1893 yllında tasfiye edilmiștir (Kazgan, 2014: 126).

\subsubsection{Austro-Türk Bankası}

Avusturya-Türk Bankası Mart 1872'de 2 Milyon Sterlin sermaye ile kurulmuștur. Merkezi Viyana șehrinde bulunan Banka'nın kurucuları Osmanlı "Société Généralé"i, Christaki Zografos, A. A. Ralli, J. Camondo ve Ortakları, C. Carapanos, S. Stefanovitch, Otto Ullman, Antoine Vlasto, Viyadaki Union Bankası ile İngilizAvusturya Bankası ve bazı ünlü bankerlerden olușmaktadır (Özdemir, 2009: 39).

Söz konusu bankanın çalıșma alanını sanayi, ticari ve zirai ișlerle her türlü sarrafiye ișlemleri olușturmaktadır. Bankanın sermayesi 2.000.000 Sterlin olup, her biri 20 Sterlin olmak üzere 100.000 hisseye bölünmüștür. Ayrıca sermayenin 4.000.000 Sterline kadar çıkarılabileceği ilan edilmiștir. Avusturya-Osmanlı Bankası'yla birlikte kurulan Austro-Türk Bankası 1873 yılında mevcutlarını Osmanlı Bankası'na devrederek kapanmıștır. Kapanmasının nedenleri arasında en önemlisi Viyana Borsası'ndaki spekülasyonlar krizidir (lipek, 2011 : 188).

\subsection{Camondolar'ın Osmanlı Mali Sisteminin ve Ticaret Kanunlarının Olușturulmasındaki Rolleri}

Osmanlı İmparatorluğu'nda Tanzimat Dönemi devletin idari, siyasi, sosyal, kültürel, ekonomik vd. birçok farklı açıdan dönüșümün yașandığı bir dönem olmuștur (Akyıldız, 2007: 506). İmparatorluk, bu dönemde yașamakta olduğu uzun süren savașlar ve iç isyanları durdurmak için verdiği mücadeleler sebebiyle karșılaștığı masraflar ile sürekli hale gelen bütçe açıklarını kısa zamanda ödeyebilmek amacıyla, XVII. yüzyıldan bașlayarak orta ve kısa vadeli çeșitli parasal önlemleri uygulama yoluna gitmiștir. 1854 yılında yapmıș olduğu ilk dıș borçlanmaya kadar olan süreçte, Osmanlı Imparatorluğu ihtiyaç duyduğu parasal kaynakları büyük oranda 1775'te yürürlüğe koymuș olduğu "Esham Sistemi'yle karșılamıștır. 1775-1840 yılları arası esham uygulamasıyla gerçekleșmiș olan iç borç stoku, devletin merkezi gelir oranının yarısını așmaktaydı. 
Dıș borçlanmaya bașvurulmasının nedenleri arasında önem arz eden olgu, Esham sebebiyle olușan iç borç stokunun en azından belirli bir kısmını ödeyebilmektir. Fakat dıș borç alınan dönemlerde dahi, esham uygulaması farklı yöntemlerle sürdürülmüștür. İmparatorluğun yaptığı istikrazlar ile esham ve iltizam sistemleri, Osmanlı mali sistemi ve ticaret kanunlarının olușturulmasının önünü açmıș; bu durum, bütçe açıklarını kapatmaya ve gelirleri artırmaya yönelik çözüm teklifleri getirmekle birlikte, maliyenin yașamıș olduğu bunalıma kalıcı çözümler getirememiștir (Aydın, 2002: 605-608). Camondolar'ın da söz konusu kimi kanunların meydana getirilmesinde aktif bir rol üstlenmișlerdir.

\subsubsection{Camondolar ve Esham-ו Cedide Kanunu}

Eshamın kelime anlamı ise, Arapça pay manasında ki "sehim" kelimesinin çoğuludur. Osmanlı hukukunda miras ve vakıflarla alakalı metinlerde bu manada kullanılmaktadır. Bir mali terim olarak ise ilk defa, 1775 yılında I. Abdülhamid Döneminde (hd. 1774-1789) hayata geçirilmiș ve 1840'ta kâğıt paranın kullanılmaya bașlamasına kadar süregelen belirli bir iç borçlanma sistemini ifade etmektedir (Genç, 1995: 377). Bir diğer anlamıyla ise "Esham uygulaması temelde bir iç borçlanma ameliyesinden bașka bir șey değildi. Fakat gelir ortaklığı sisteminin ilk ve orijinal bir örneğiydi." (Tabakoğlu, 2014: 270). Esham sistemi genel nitelikleri açısından malikâne ve iltizam sisteminin bir bileșimini olușturmaktadır. Esham sisteminin malikâne sisteminden farkı ise bir mukataanın senelik kazancının hepsi yerine, sadece senelik kârının belirli hisseler șeklinde "ber veche malikâne" satıșını ifade etmesidir. Avrupa devletlerine göre uzun bir süre sonra çağdaș borçlanma modellerini kullanan Osmanlı İmparatorluğu, mali buhranların üstesinden gelmek için iltizam, malikane ve piyasadaki paraların ayarlarının düșürülmesi gibi çeșitli klasik iç borçlanma modellerini kullanmıștır. Fakat, XVIII. yüzyılın son çeyreğinde, 1775 yılında hayata geçirdiği ve dönemin koșulları göz önüne alındığında gayet modern sayılabilecek esham uygulamasıyla Avusturya ve Rusya'ya karșı yaptığı uzun süreli ve yüksek maliyetli savașların finansmanı karșılayabilmiștir. Bu sistemi 1840 yılında uygulamaya koyduğu kâğıt para sistemiyle geliștirmiș;; 1854 yı- 
lında da dıș borçlanma yaparak önemli mali kaynaklar sağlamıștır. Ancak gerçekleștirilen bu uygulamalar, kazanılan finansmanın cari harcamalarda kullanılması ve gelir getiren yatırım kaynaklarına aktarılmaması gibi nedenler sebebiyle beklenen bașarı sağlanamamıș ve Osmanlı İmparatorluğu'nun 1875 yılındaki mali iflasının sürecini hazırlamıștır (Aydın, 2002: 613, 614). Osmanlı İmparatorluğu kamu borçlanmalarına uzun bir süreç sonunda ve kısıtlı ölçüde bașvurmuștur. Padișahlara ait iç hazine, uzun süre devlet hazinesinin kredi gereksinimini karșılamaya yeterli olmuștur. Bunun yanı sıra kısa vadeli kredi ihtiyacını karșılamak üzere devlet adamlarına, tüccarlara ve sarraflara belli ölçülerde de olsa bașvurulmuștur (Genç, 1995, 377).

Osmanlı İmparatorluğu'nda Esham sistemi iç borçlanmayı müzayedeleri domine eden az sayıda büyük sermaye sahiplerinden daha fazla sayıda, küçük ve orta ölçekli sermaye sahiplerine doğru genișletmek amacındaydı. Ancak, İmparatorluğun Esham paylarının kișiler arasında alım ve satımını önleyememesi ve ilk esham sahiplerinin ölümünden sonra varislerin de imparatorluktan kazanç sağlamaya devam etmeleri sebebiyle, uygulanan bu yeni sistemin faydaları sınırlı kalmıștır (Pamuk, 2014: 138).

Ağırlașan mali sorunlar ve dıș kaynak bulmakta çekilen güçükler nedeniyle faizli hisselerin üç, faizsiz eshamların ise iki yılda piyasadan çekilerek yerlerine yeni kâğıtların çıkarılmasına karar verilmiștir. Gelinen noktada devlet maliyesinin iç borçlanmaya bașvurmadan yașaması olanaksız hale gelmiștir. Avrupa'dan borçlanma sürecinde gerçekleșecek görüșmelere de hazinenin karșı koyması mümkün olmadığından dolayı, Avrupa'dan alınacak borca değin cari harcamaları karșılamak için İstanbul Emtia Gümrüğü malından Esham-ı Mümtâze çıkarılması kararlaștııılmıștır (Erdem, 2006: 10). Arkasında devlet garantisi olan Esham ve benzeri kâğıtlar halk tarafından da benimsenmiștir. Yeni kâğıtların dördüncü tertibi Avrupa'da bile alıcılar bulmuștur (Anonim, 2009: 10).

Faiz getirisi \% 6 olan bu kâğıtlar 1859'dan itibaren piyasaya sürülmeye bașlanmıștır. 1862 yılının ilk ayında bu kâğıtların piyasadaki hacmi 5.000.000 Mecidiye Liraya ulașmıștır (Akar, 
2001: 2). Osmanlı'da 1839'da kaime adıyla piyasaya sürülen ilk kâğıt paranın ayarlarıyla sık sık oynanması sonucu doğacak olan buhranı engellemek için bu kanuna bașvurulmuștur. Piyasadan toplanmaya çalıșılan kaimenin yerini alması düșünülen bu sistem amacına ulaștıılamamıștır. Esham-ı Cedide ile gerçekleșecek olan yeni iç borçlanmadan elde edilen gelir, hazinenin acil ihtiyaçlarının karșılanması, kaime ve Esham-ı Mümtaze'nin (borç tahvilleri) piyasadan çekilmesi için kullanılacaktır (lpek, 2011 : 189).

Esham-ı Cedide ile elde edilen gelirlerin bir sandıkta biriktirilmesi ve devletin ihtiyacı anında kullanılması amacıyla Tediye Sandığı kurulmuștur. Alınan kararlara göre elde edilen gelirlerin planlanan bir yer dıșında kullanılmayacağı ve istikraz olarak karșılık gösterilmeyeceği kararlaștırılmıștır. Tediye Sandığı, Esham-ı Cedide için olușturulmuș bir kurum olup bu kurumun komisyon üyeleri arasında Abraham Camondo da yer almaktadır. Bunun denetimi; olușturulan komisyon tarafından sağlanacak ve takip edilecektir. Çıkarılan nizamnamede 1.000.000 kese olarak belirtilen piyasaya sürülecek esham-ı cedide miktarı, en bașta 2.500.000 kese olarak düșünülmüștür. Ancak bu kadar çok miktarda piyasaya sürülen eshamların daha en bașta kendi değerini düșüreceği endișesiyle sayı 1.000 .000 'a indirilmiștir. Ağustos 1859'dan Mart 1862 tarihine kadar üç parça olmak üzere toplam 5.000.000 Mecidiye Liralık esham-ı cedide çıkarılmıș ve nizamnamede belirlenen miktara ulașılmıștır (lipek, 2011 : 192).

\subsubsection{Iltizam Sistemi İçerisindeki Rolleri}

Iltizam devlete ait gelir kaynaklarının, bir kısmı peșin kalanı taksitler halinde ödenen paralar karșilığında kișilere bırakılmasıdır. Bu müteahhitlere "mültezim" deniliyordu. Bunlar, iltizam konusu geliri devlet güçlerine dayanarak toplarlar, ödediklerinden fazlası kazançlarını oluștururdu. Toprak iltizamına mukataa adı verilirdi. Ayrıca daha fazla bir para ödenmesi koșuluyla da toprakların yașam boyu aynı kișiye, ölümünden sonra da çocuğuna bırakılması mümkündü. Buna ise "Berveçh-i Mâlikhane" denilirdi (Sakaoğlu, 1985: 60). Osmanlı́nın ilk zamanlarından itibaren kullanılmaya bașlayan bu sistemde, devletin uyguladığı politika 
genellikle belirli bir mekânla sınırlı kanuni veya șer'î vergi öğelerinden olușan mukataa birimlerini devretmișțir (Buluș, 2010: 94).

Illtizam Sistemi ile hazine, bir eyaletten vergi toplama yetkisini resmi yönetici zümre üyelerinin dahil olduğu ve belirli zaman aralıklarında gerçekleștirilen ihalede en yüksek tutarı ödemiș olana vermekteydi. Yapılan sözleșmenin mültezimlerinin hazineye her yıl ödemekle yükümlü olduğu miktar, nominal değerinin sabit bir miktarıydı. Sözleșmenin mültezime köylülerden toplama görevi verdiği vergi miktarı ise gerçek üretimle orantılı bir șekildeydi. Mültezimin devletle gerçekleștirdiği sözleșmedeki miktardan daha fazla oranda topladığı vergi hasılatını kâr olarak alabilmekteydi. Devletin hazinesine girmiș olan reel vergi gelirleri, yöntem olarak, tekrar gerçekleștirilecek olan ihalelerle düzenlenecek, bu șekilde, ihale tutarları beklenen kazançları iskonto edecek, o günkü reel değerini yansıtması sağlanacaktı (Kıray, 1995: 184). iltizam sistemi Akdeniz'den Hint Okyanusu'na kadar tüm İslam devletlerinde, Ortaçağ'dan XIX. ve XX. yüzyıla kadar vergi toplamanın en geniș ve yaygın șekli olarak kullanılmıștır (Pamuk, 2014: 13).

Illtizam Sistemi'nin XIX. yüzyılda Tanzimat Fermanı ile angarya gibi yükümlülükleri kaldıracağını ilan ettiği halde, yașanmakta olan olaylar bu olgunun imkânsızlığının anlașılmasını sağlamıștır. Yavaș modernleșen devlette merkezi bürokrasi modern maliye örgütünün gereksinimlerini yerine getirecek durumda değildi. Hatta bazı bölgelerde uygulanan iltizam sisteminin iyi ișleyiși bile $1880^{\prime}$ den sonra faaliyete geçen ve bazı vergi giderlerini domine eden Düyun-u Umumiye'nin müdahalesi ile olanaklı hale gelmiștir (Ortaylı, 1987: 172).

XIX. yüzyılda Illtizam Sistemi'nin yanında mali teșkilat içerisinde gerçekleștirilen bir diğer değișiklik ise "muhassıllık" uygulamasıdır. 1840 yılında, iltizam sisteminden vazgeçilerek yerine muhassıl olarak adlandırılan geniș yetkiler verilmiș kamu görevlileri, vergilerin toplanmasında faal hale getirilmiștir. Sancak ve eyaletlerde görevlendirilen muhassıllar tahrir ișlemlerine ek olarak Tanzimat Fermanı ile gerçekleștirilen yenilikleri halka anlatmak gö- 
revini de üstlenmișlerdir. Muhassıllar, bölgelerde tahrir ${ }^{5}$ ișlemleriyle o bölgelerde bulunan tebaanın emlak ve arazilerini kayıt altına alınmasını sağlamıștır. Muhassıllara görevlerinde destek sağlaması için kâtipler, tahriri yapılan bölgedeki kadılar ve din adamları da görevlendirilmiștir. Yaklașık iki yıl devam eden bu sistem vergi memurlarının sayısının az olması ve devletin bu uygulamasından memnun olmayan mültezimler tarafından karșı çıkılması nedeniyle bașarılı olamamıștır. Bu sistemin uygulanamaması üzerine tekrar iltizam sistemine dönülmüștür (Oğlakçı, 2007: 29).

Bu koșullar altında Abraham Salomon Camondo'nun etkin dönemi olarak adlandırılabilecek XIX. yüzyılın ikinci yarısından itibaren en büyük kârlarını sağladığı kefalet sistemi aynı zamanda büyük zararları da beraberinde getirmiștir. Illtizam sistemi uygulayan Osmanlı İmparatorluğu mültezimler aracılığıyla toplanacak verginin önemli șartlarından biri, mültezimin büyük bir kefile ihtiyaç duymasıydı. XIX. yüzyılın önemli bankerlerinden olan Camondo'nun devlet tarafından uygun görülmesi kefillik için yeterli bir șarttı. Bu durumdan yararlanan mültezimler ve Camondo Ailesi devlet nezdinde büyük kazançlar sağlamıșlardır. Bunun yanı sıra mültezimlere kefil olan Camondo'nun Trabzon ve civarı gümrük vergileri için büyük zararlara uğradığı bilinmektedir. Camondo'nun vergi kazançları tek mültezimler ve kefalet aracılığıyla olmamıș aynı zamanda iltizamın doğrudan alınmasıyla olmuștur. Devlet tarafından ihale edilen iltizamların büyük sarraflar tarafından kefil gösterilmeksizin alınması Camondolar'ın Osmanlı İmparatorluğu'ndaki yeri ve önemini göstermesi açısından yeterlidir (lipek, 2010: 207-210).

\subsubsection{Hazine ille Olan ilișkileri ve Sağladıkları İstikrazlar}

İstikraz, vadesi dolduğunda ödemek koșulu ve belirli faiz karșılığı alınan borca ilișkin sözleșme anlamına gelmektedir. İç ve dıș istikrazlar, Osmanlı İmparatorluğu için 1845'ten sonraki bütçe uygulamalarında, bir sorun olarak ortaya çıkmıștır. Daha önceleri munzam vergiler, iltizam ve mukataa zorlamaları ile mali durumu

5 Tahrir: Osmanlı mali teșkilatında vergi tespiti amacıyla yapılan sayıma verilen isimdir. 
dengede tutmaya çalıșan devlet, XIX. yüzyılın ikinci yarısında hızlı dıșa açılma ve israf (lüks) yüzünden dıș baskıların tutsağı konumuna gelmiștir (Sakaoğlu, 1985: 61, 62).

Osmanlı İmparatorluğu'nun aldığı iç borçlar kısa vadeli sorunları çözse de uzun vadede sıkıntıların artmasına neden olmuștur. Devleti borçlanmaya yönelten en büyük ihtiyaç ordunun masraflarının karșılanması noktasında yașanmıștır. XIX. yüzyıldaki ihtilalci fikirlerden etkilenen Balkanlar ile etnik ve dini anlașmazlıklar nedeniyle Ortadoğu'da sık sık çıkan ayaklanmalar orduyu ve hazineyi oldukça güç duruma sokmuștur. Böyle durumlarda bașvurulan ilk kaynaklardan biri Camondolar olmuștur. Örneğin, 1848 Fransız Devriminden etkilenen Eflak ve Boğdan'da çıkan olayları bastırmak için görevlendirilen Osmanlı ordusunun acil ihtiyaçları için poliçe karșilığında 4.000 kese Akçe için Camondo Ailesine bașvurulmuștur. Yine vergilerin zamanında toplanamamasından dolayı hazinede olușan açık Camondolar aracılığıyla kapatılabilmiștir (İpek, 2011: 214). Camondo'nun İstanbul'daki bankası dâhil olmak üzere hemen bütün Galata bankaları ve bankerleri, her zaman olduğu gibi bu defa da Osmanlı Hükümeti'ne, kendilerine olan kısa vadeli borçlarını ödeyebilmesi için bir dıș istikraz anlașması yapılmasını önermișlerdir (Kazgan, 2014: 345). Aslında hükümetin Osmanlı Bankası'na 4.500.000 Frank ve gerisi diğer Galata banka ve bankerlerine ait olmak üzere 6.000.000 Franktan fazla kısa vadeli borcu bulunuyordu. Osmanlı Bankası tarafından organize edilen istikrazın Mayıs 1886'da imzalanması hükümetin Galata piyasasında yeniden kredi sağlayabilir duruma gelmesini sağlamıș ve hükümet Osmanlı Bankası ve diğer Galata bankerlerinden 500.000 Osmanlı Lirası kredi almak için görüșmelere bașlamıștır. Bu 500.000 Liralık istikraz yanında Osmanlı Bankası aracılığıyla yapılacak istikraz 6,5 Milyon Frank tutarındaydı. İhraç edilen tahviller \%5 faiz getirdiği gibi \% 1 oranında da amortisman payı ödenmesine hak kazanıyordu. Bu istikrazın yıllık faiz ve amortisman taksitlerini garanti edebilmek için hükümet; İzmir, Bursa, Beyrut, Edirne ve Selanik gümrük hasılatı üzerinden her yıl 390.000 Osmanlı Lirasını tahsis etmiștir (Kazgan, 2014: 345-346). 
1869 yilında Camondolar'ın İstanbul'dan Paris'e yerleșmiș olmaları Osmanlı İmparatorluğu ile borç ilișkilerini bitirmiș oldukları anlamını tașımamaktadır. Geçmiș yıllarda alınanların ödemeleri yanında yeniler de bunlara eklenmeye devam etmiștir. Nitekim Camondolar Paris'e gittikten sonra İstanbul ekonomi çevreleri ve devletle olan mali ilișkilerini koparmamak için her türlü özeni göstermișlerdir. Bununla birlikte Osmanlı İmparatorluğu'nun Avrupa ile olan istikraz ilișkileri içinde de rol oynamıșlardır. Ancak zaman geçtikçe Camondolar Osmanlı İmparatorluğu ile olan istikraz ilișkilerine sınırlamalar getirmeye bașlamıșlar, İstanbul'dan yavaș yavaș ellerini çekmișlerdir. Aslında tamamen çekiliș Kont Abraham Behor Camondo'nun ölümünden sonra gerçekleșmișse de, onun son zamanlarında bir toparlanma görülmektedir. Vekiller aracılığıyla yürütülen İstanbul'daki ișler onlar için kazançtan çok bir sıkıntı haline gelmeye bașlamıștır. Nitekim Abraham Camondo 1886 yllında yine bir istikraz için kendisine bașvurulduğunda hükümet temsilcilerine "Istanbul'da muamelatı olmadığından istikraza katılamayacağını" bildirmiștir (lpek, 2011 : 223-224).

\section{3. Çeșitli Sektörlerdeki Yatırım Faaliyetleri}

XIX. yüzyılın ikinci yarısı mali ve iktisadi açıdan Osmanlı İmparatorluğu için bir dönüm noktası olmuștur. Mehmet Emin Ali Pașa ölmüș, yerine adı birçok mali olaylara karıșmıș, özellikle Galata Borsası ve Galata Bankerleriyle çok yakın ilișkide olan Mahmut Nedim Pașa sadrazam olmuștur. Bu dönemde iki kez sadrazam olan Mahmut Nedim Pașa'nın sürdürdüğü iktisadi ve mali politika, Galata Bankerlerinin ekonomi içerisindeki ağırlığının artmasını sağlamıștır. Bunlar bankerlik dıșında her zaman yaptıkları iltizam ișinin yanında bu defa tramvay, demiryolu, inșaat, rıhtım, su șirketleri, belediyeciliğin kurulumuna etkileri vd. gibi birçok alanda etkili olmușlardır. Bu dönem 1881'deki Muharrem Kararnamesi'ne kadar sürmüș ve Osmanlı İmparatorluğu'nun adeta tüm gelirlerinin ipotek altına alınmasına, ekonomide ise gelir dağılımının olumsuz etkilemesine neden olmuștur (Kazgan, 2014: 118).

Söz konusu bu iktisadi koșullar alında Camondo Ailesi'nin bașkent İstanbul'da birbirinden farklı çeșitli sektörlerde faaliyetlerde bulundukları görülmektedir. 


\subsubsection{Dersaadet Su Șirketi}

1883 yılına kadar Pera ${ }^{6}$ ve çevresinin su ihtiyacını, $1732^{\prime}$ de faaliyete geçen Taksim Suyu sistemi ile karșilanmaktaydı (Avcı, 1994: 253). XIX. yüzyılda, kentin gelișimi ile birlikte, artan su gereksinimi eskisinden daha çok önem arz etmeye bașlamıș, özellikle inșa edilen yeni binalara basınçlı su verilmesi ihtiyacı ortaya çıkmıștır. Bu sebeple Terkos Gölüsnden șehre su getirilmesi planlanmıș ve 1874 'te yabancı bir șirketi temsil eden Hariciye teșrifatçısı Kâmil ve Mühendis Terno șahsına 40 yıl süreli bir imtiyaz verilmiștir. Gerçekleștirilen sözleșmeye göre, Terkos Gölü'nden getirilecek suyun Pera, Galata ve Haliç'in batı sahiline ve Boğaziçi'nin Rumeli yakasına isale hattıyla ulaștırılması; hastane, kıșla, okul ve belli bölgelerdeki 12 çeșmeye günün belli saatlerinde ücretsiz su verilmesi koșuluyla, geri kalanın șirket tarafından tesisat kurularak hanelere ve halka da satılması kabul edilmiș ve böylece evlere bağlanmıș olan ilk șehir suyu ve aboneliği bașlamıștır (Anonim, 1994: 48). Verilen bu imtiyaz, ilerleyen süreçte "Dersaadet Anonim Su Șirketi" adıyla kurulan Fransız șirketine devredilmiș ve $1887^{\prime}$ de gerçekleșen sözleșme ile imtiyaz süresi 75 yıla çıkarılmıștır. Cumhuriyet döneminde șirketin adı "İstanbul Türk Anonim Su Șirketi" olmuștur. Toplumda "Terkos Șirketi" olarak bilinen Dersaadet Anonim Su Șirketi, ilk olarak 1883'te Terkos Gölü kenarında, günümüzde de hâlâ var olan pompa istasyonu binasını yapmıștır. XIX. yüzyılın sonlarında Anadolu Yakası'nda ki su tesislerinin yetersizliğinden dolayı yeni tesislerin yapılması zorunluluğu doğmuștur ve 1888'de yapılan sözleșme ile bir Fransız șirketini temsil eden Karabet Sivacıyan'a 65 yıl süreli bir imtiyaz verilmiș, 7 Haziran 1914'te yenilenen sözleșmeyle imtiyaz süresi 99 yıla çıkarılmıștır (Çelebi, 1994: 234).

Galata Bankerlerinin neredeyse tamamının ortak olduğu ve ilk adı İstanbul Kızıldere Su Șirketi olan bu kurulușun 30 Haziran

6 Galata ve Pera, Beyoğlu İlçesi'nin güney ve doğu sınırlarındaki yerleșim merkezlerinin 19. yüzyıldaki adlarıdır. Pera, Galata'nın kuzeyinde Tünel ile Taksim arasında kalan, İstiklal Caddesi ve bu caddeye açılan sokakları kapsayan alandır (Çelebi, 2011: 301). 
1874 tarihinde yürürlüğe giren nizamnamenin 8. Maddesinde șirketin sermayesi hakkında șu hükümler bulunmaktadır:

"Madde 8: Șirketin sermayesi, 1 milyon 650 bin Osmanlı alıını, yani 1 milyon 500 bin Ingiliz lirası olup her biri 22 Osmanlı altını yani 20 Ingiliz lirası kıymetinde 75 bin hisseye ayrılmıș olacaktır. Șirketin sermayesi birkaç tertipte çıkarılabilecek ve sermayenin en az yarısı imza olunduğu ve imza olunan her hissenin dörtte biri tediye kılındığı anda șirket muamelata bașlayabilecektir. Hissedarların dörtte üçünün bizzat veya vekalet suretiyle hazır bulunduğu bir genel kurulda ekseriyet oyu ile karar verilir ve bu karar Taraf-ı Saltanat-ı Seniye dahi tasdik buyrulur ise sermayenin miktar-ı asliyesi yeniden hisse ihracı ile arttrılabilecektir." (Kazgan, 2014: 288).

Kurucu hissedarların hemen hepsi Paris kaynaklı ve Fransız sermayesi ile kurulmuș olan bu șirketin içinde Camondolar'ın da yer alması bir tesadüf değildir. Nitekim bu tarihte Camondolar Paris'te yașamaktadır ve Paris'in önde gelen șirketleriyle böylesine bir ortaklığa girmek onlar için büyük bir firsat olmuștur. Paris finans dünyası içinde kendine yer arayan Camondolar böylece Paris ve İstanbul dengesini olușturmaya çalıșmıșlardır (lipek, 2011 : 204). Camondolar'ın da hissedarı olduğu șirketin beklenen talebi sağlayamaması bir takım önlemler alınmasına neden olmuștur. Bu bağlamda en önemli tedbir su fiyatlarının artırılması olmuștur. 156 Liraya satılan 1 metreküp suyun 160 Liraya çıkarılması veya mukaveleye göre Osmanlı lirasını 108 ve Mecidiyeyi 20 Kuruș'a kabul etmesi gerekirken, bazı zamanlarda Mecidiye'yi 18,5 Kuruș'a kabul ederek ișlem yapmıștır. Bu șekilde kazançları artan șirketin yıllık kâr paylașımı ise șu șekilde belirlenmiștir: Hisse senetlerinin faizi olarak \%6, geri kalan üzerinden \%5 îhtiyat Akçesine, \% 10 idare meclisine, $\% 15$ kuruculara ve $\% 70$ temettü olarak hissedarlara dağııılacaktır (İpek, 2011 : 206-207). Bu șekilde yeni yollara bașvuran Șirket, kurucularından olan Camondolar'a da büyük karlar sağlamıșlardır. 


\subsubsection{Belediye Hizmetleri}

Osmanlı İmparatorluğu'nda belediye kurulmadan önce sistem kadı, vakıflar, loncalar ve mahallelerden olușmaktaydı. Kadı, yargı gücüne sahip konumda bulunmaktaydı. Vakıfların denetleyicisi de olan kadı, beledi-mahalli güvenlik ve denetim hizmetlerinin de amiri konumunda bulunmaktaydı. Vakıflar șehrin sosyal kurulușlarını yapmalarının yanı sıra, meslek kurulușları olan loncalar çarșı ve pazarların düzen, temizlik ve aydınlatma ișlerine bakıyorlardı. Șehirde, piyasadaki malların satıș bedelini düzenleyen, gerektiğinde önlemler alabilen bir muhtesipler kurulunun bulunduğu ihtisap müessesesi kurumu da bulunmaktaydı. Mahallelerde ikamet eden halkta kendi bekçisini seçiyor aynı zamanda mahallenin zorunlu ve benzer ortak yerel ihtiyaçlarını karșilıyordu (Sunay, 2002: 117).

XIX. yüzyıl ve Tanzimat, İstanbul'un kaderinde bir dönüm noktasını olușturmuștur (Toprak, 1993: 128-140). İstanbul kenti yöneticiliği (Șehir Eminliği) 16 Ağustos 1854'te kurulmuștur. Yeni örgütün görevi belediye hizmetlerini yerine getirmektir (Sakaoğlu, 1985: 120). İstanbul'da Șehremaneti'nin kurulușunun önünü açan önemli bir etken olan Kırım Savașı'ydı. Rusya ile yapılan bu savașta Osmanlı İmparatorluğu'nun müttefikleri olan Avrupalı İngiliz, Fransız ve İtalyan ordularının bașkent İstanbul'a gelmesi șehrin nüfusunu așırı derecede artırmıș; temizlik, sağlık ve ulașım sorunları hızla büyüyerek içinden çıkılmaz hale gelen bir kaos yaratmıștır. İhtisab Nezâreti'nin de bu sorunları çözememesi nedeniyle, belediye hizmetlerini yerine getirecek yeni bir kurum olușturmaya sevk etmiștir. Resmi gazete Takvim-i Vekayi'de yayınlanan bir duyuru ile "...șehremâneti ünvânıyla bir me'mûriyyet-i cedîde yapılması ve... Șehir Meclisi nâmıyla bir meclis dahî teșkîl olunması..." kararlaștırıldığı kamuoyuna açıklanmıștır. Șehremânetinin bașlıca görevleri: 1- Zorunlu ihtiyaç maddelerinin teminini kolaylaștırmak ve gözetmek, 2- Fiyatların belirlenmesi (narh) ve bunun kontrolü, 3- Șehrin temizliğinin sağlanması, 4- Çarșı ve pazarın denetimi, 5- Vergilerin toplanarak maliye hazinesine devredilmesi. Șehremâneti, Șehremini denilen görevli tarafından yönetilecek ve șehirle ilgili karaların alınması ve yürütülmesinde bu nizamnâmeyle olușturu- 
lan Șehir Meclisi ile birlikte çalıșacaktı. Șehir Meclisi İstanbul'da yașayan her sınıf tebaadan ve önde gelen esnaf temsilcilerinden olușan 12 kișinin yanı sıra, meclise bașkanlık edecek olan șehremini ve onun 2 yardımcısı ile toplam 15 üyeden olușacaktı. İhtisab Nezareti'nin yerine kurulan Șehremâneti, kurulușundan sonra ki yıllarda beklentilerin alıında bir bașarı sağlamıștır. Bu nedenle, 1855 yılında Șehremâneti'ne yardımcı olmak için İntizâm-ı Șehir Komisyonu olușturulmuștur. Bu komisyonun uğrașları sonucu 1857 yılında İstanbul șehri çevresiyle beraber 14 belediye bölgesine ayrılmıștır. Pilot bölge olarak (Pera ve Galata bölgeleri) Altıncı Daire-i Belediye, Șehremâneti'ne bağlı olarak kurulmuștur. Șehremâneti ve Altıncı Daire-i Belediye 1877 yılına kadar bu șekilde çalıșmıșlardır. 1877'de yürürlüğe konulan Dersaadet Belediye Kanunu ve Vilâyât Belediye Kanunu ile imparatorluğun yerel yönetim sorunlarına daha köklü çözüm getirilmeye çalıșılmıștır (Seyitdanlıoğlu, 2010: 3-4). Olușturulan bu meclise, seçilme koșulu olarak adayın Altıncı Daire sınırları içerisinde en az 100.000 Kuruș değerinde emlak sahibi olması ve en az 10 yıldır İstanbul'da ikamet ediyor olması gerekiyordu. Meclisin asli üyelerine ek olarak, Babıâli, 4 yabancı danıșman atayacaktı. Bu danıșmanların belediye konularında bilgi sahibi, ayrıca en az 200.000 Kuruș değerinde emlak sahibi ve İstanbul'da 10 yıl süreyle ikamet etmiș olmaları gerekiyordu (Celik, 1986: 38).

Bu değișim-dönüsșüm sürecinde Camondolar'ın büyük bir kısmını iș hanlarının olușturduğu emlaklarının önemli bir bölümü Beyoğlu-Galata'da bulunduğundan, Altıncı Daire içinde oynadığı aktif rolü tahmin etmek güç değildir. Camondolar'ın adı "belediye dairesi içinde emlakı olup mecliste müșavir sıfatı ile bulunacak kimseler" arasında geçmektedir. Bu kez Abraham Camondo değil, "Camondo'nun oğlu" bu grupta yer almıștır. Alyon, Septim Frankıni ve Hanson, "Camondo'nun oğlu" ile birlikte bu göreve seçilen diğer isimleri olușturmuștur. Ancak ilk meclisin olușturulduğu Aralık 1857 tarihinde "Camondo'nun oğlu" ismine rastlanırken, bundan kısa bir süre sonra 30 Mart 1858 tarihinde belediye meclisinin hazırladığı bir mazbatada Abraham Camondo'nun ismi geçmektedir (lipek, 2011 : 228-232). 
Altıncı Daire'nin 100.000 Liraya yaklașan borçları ile AlıınCı Daire'nin istikrazlar konusunda itibarı iyice sarsılmıștır. Yapılması gereken yollar ve yangından zarar gören yerlerin onarımı; kaldırım ve lağımların inșası için gerekli para bulunamayınca Altıncı Belediye'de ıslahat yapılmasına karar verilmiș, mali durumu düzeltmek için de bazı tedbirler önerilmiștir. Bu tedbirlerden en önemlisi daire meclis heyetinin ve idaresinin değiștirilmesi konusunda olmuștur. Alıncı Daire-i Belediye Dairesi'nden sonra diğer belediye örgütlenmeleri de faaliyete geçirilmiș olmasına rağmen aslında Altıncı Daire tam olarak beklenenleri yerine getirememiștir. Bölgenin fiziki ve toplumsal olarak yeniden yapılandırılmasından çok, Galata iș çevrelerinin konumunu güçlendirmeye yaramıștır (ipek, 2011: 228-232).

\subsubsection{Meriç Nehri'nde Vapur İșletmeciliği}

1857 yılında imtiyazı alınan Meriç Nehri'nde yolcu ve yük tașımaya yönelik girișimde Camondo bașta olmak üzere Kran, Nissim Enkaza, Boyacıoğlu Kistaki gibi tüccarlar da bulunmaktadır. Bu girișimin, İnöz'den (Ege Adalarından) Edirne'ye ve oradan da Filibe'ye kadar vapur ișletme talebi Osmanlı İmparatorluğu tarafından olumlu karșilanmıștır. İmtiyaz mukavelesinden anlașıldığına göre, ișletilecek vapurların yolcu ve yük tașımak üzere iki ișlevi olacak ve yük tașıma kendilerine ait olan muhafazalı (korumalı) ve rabıtalı (düzenli) salları çektirmek șeklinde yapılacakıır. İmtiyaz süresi 22 yıl olarak belirlenmiștir. Camondo ve ortaklarına bu 22 yıl içinde herhangi bir șey olduğu takdirde varisleri bu imtiyazı devralabilecektir. Yolcu ve yük tașıma tarifesi de mukavelede belirlenmiștir. Ayrıca vapurlar hasılatından elde edilecek gelirin masrafları düsüldükten sonra geriye kalanın üzerinden \%20 "vergi-yi mahsus" olarak devlete ödenecektir. Önemli maddelerden birisi de Edirne Sancağındaki Dimetoka ve diğer kazaların sınırları dâhilinde çıkabilecek kömür madenleriyle ilgilidir. İmtiyaz süresi içinde buralarda çıkacak kömür madenlerini ișletme ruhsatı imtiyaz sahiplerine ait olacaktır. Çıkarılacak kömür madeninden devlete \%10 vergi ödenecek, ayrıca imtiyaz sahipleri vapurlar için gerekli olan kömürün fazlasını ticaret amacıyla dahile ya da harice satabilme hakkına sahip olacaktır. Buna karșılık ödemek 
zorunda oldukları \% 10 vergiden bașka bir de ticaret amacıyla sat†ığı kömürlerin satıș fiyatı üzerinden \%12 gümrük vergisi vermeye mecbur olacaklardır. Bununla birlikte 22 yılı bile tamamlayamadan vapur ișletmesi sona ermiștir.

Vapurlar ișlemeye bașladıktan bir süre sonra, Rumeli demiryolu hattının Dedeağaç'a kadar gelmesiyle burada bir liman tesis edilmesi ve nehrin üzerinde değirmen bentleri yapılması ișletmenin sonunu hazırlamıștır. Nitekim bu gelișmelerle birlikte kumpanyanın (șirket) gelirleri ve ișleyiși sekteye uğramıștır. Camondo ve ortakları bu nedenle girișimi sona erdirmișler, böylece mukavele de feshedilmiștir. Camondo bu zarardan devleti sorumlu tutmuștur. Nitekim devlet değirmen bendlerinin tamamen ortadan kaldırılıp vapurların rahat ișleyișini sağlamak konusunda pek de yardımcı olmamıștır. Bu nedenle Camondo 1861 yılı sonlarında "Camondo Kumpanyası" adına devlete çektiği protestoda, ortaya çıkan zarar ve hasarın karșılığında bir vapur ve mevcut eșyanın devlet tarafından satın alınmasını talep etmiștir. Ancak yapılan görüșmeler sonucu Camondo'nun teklifi kabul edilmemiș, bunun üzerine Camondo kararı kabul etmediğine dair bir protesto daha çekmiștir. Konu ile ilgili daha sonra kararda bir değișiklik yapılıp yapılmadığı hakkında bir belgeye rastlanmamakla birlikte, yarım asır kadar sonra Meriç Nehri kıyısında eskimiș bir halde bulunan bir adet römorkör teknesi ile altı adet demir duba Camondo'nun itirazının kabul edilmediğini göstermektedir (lipek, 2011 : 233-236).

\subsubsection{Ulașım Sektörü}

XIX. yüzyıl kentlerine çağdaș ulașım sistemlerinin giriși önemli bir olușumun yolunu açmıștır. Geniș ve yeni arterlerin açılması, kentlerin mahalleri arasında hızlı ve kolay ulașımı olanaklı hale getirmiștir. Daha iyi ulașım imkanları fiziki gelișmeye olanak sağlarken, aynı zamanda gelișmeyi de teșvik etmiștir. İstanbul'un coğrafi konumu, bilinen karayolu ulașım sistemlerine ek olarak buharlı gemiler yoluyla yaygın deniz yolu ulașımını sağlıyordu. XIX. yüzyılda kentin ulașım ağı birbirleriyle bağlantılı dört ana unsurdan olușmaktaydı: Deniz tașımacılığı, atlı tramvaylar, kısa bir metro hattı ve trenlerdir. İmparatorluğun bu sistemlerin yapımına giriș- 
mek için yeterli teknik donanımın olmaması ve sermaye yetersizliği, özel yatırımcılara imtiyaz tanınmasına ve belli bir süreliğine kurulan ișletmelerin tekelleșmesine neden olmaktaydı. İmparatorluğun verdiği garantiler kısa süreliğine de olsa sermaye sıkıntısını giderse de, uzun dönemde devlet bütçesinden gelir kaybına neden olmuștur (Çelik, 1986: 68).

XIX. yüzyılın en önemli șirketleri arasında sayılabilecek, devlete büyük kazançlar sağlayan Șirket-i Hayriyye ve Dersaadet Tramvay Șirketi hissedarları arasında Camondolar yine önemli rol oynamıșlardır. Kurucu ortaklara İmparatorluk kâr garantisi vermiș, olușacak herhangi bir bütçe açığını da karșılamayı taahhüt etmiș ve idari kolaylıklar sağlamıștır. Bu durumlar alında kurulan ișletmeler Osmanlı ekonomisine katkılar sağlarken, kurucu ortakların da büyük avantajlar elde etmesine zemin hazırlamıștır.

\section{a) Șirket-i Hayriyye İçerisindeki Rolleri}

İstanbul'da 1851'de kurulan, 1944 yılına kadar faaliyetini sürdüren ve 1944 yılında șirketin varlığının Devlet Denizyollarına geçtiği Türkiye'nin ilk büyük deniz ișletmeciliğidir. Söz konusu kurum önceleri Boğaziçi'nde daha sonra da İzmit, Yalova, Bandırma hattında vapur çalıștırmıș Osmanlı İmparatorluğu'nun ilk anonim șirketidir (Sakaoğlu, 1985: 122). Ocak 1851'de padișah iradesiyle kurulușuna onay verilen șirketin imtiyaz süresi 25 yıl olarak belirlenmiștir. Illk etapta ikisi gemi çekmek ve beși yolcu tașımak için kullanılacak yedi geminin saıın alınması, iskele ve binaların inșası ve diğer gerekli masrafların karșılanması amacıyla, șirketin sermayesi önce hisse senetleri piyasaya sürülerek satıșa çıkarılmıștır. Her bir adedi 3.000 kurușluk 1.500 hisse senedinin 100 adedini Sultan Abdülmecid, 50 adedini de annesi Bezmiâlem Valide Sultan almıștır. Sadrazam Mustafa Reșid Pașa 20, Serasker Damat Mehmed Ali Pașa, Tophane Müșiri Fethi Pașa, Girit Valisi Mustafa Pașa, Mısırlı Yusuf Kâmil Pașa, Kavalalı Mehmed Ali Pașa'nın kızı ve Yusuf Kâmil Pașa'nın eși Zeyneb Hanım, pașalar, valiler, çoğu banker ve sarraf olan Ermeni, Rum ve Musevi ișadamları 15'er ya da 10'ar hisse senedini alarak kurulușa ortak olmușlardır (Naza, 1994: 182). 
Abraham Camondo ilk etapta 15 hisse almakla yetinmiș ancak ilerleyen zamanlarda șirketin büyük kârlar elde etmesi sonucu Camondo da hisse sayısını 58'e çıkarmıștır. Burada dikkat çeken en önemli nokta, Mustafa Reșid Pașa'nın sarrafı ve dönemin ünlü bankeri Camondo'nun sadece 15 hisse satın almıș olması, Mustafa Reșid Pașa'nın bu ișin öncülüğünü yaptığı düșünülürse biraz anormal gözükmektedir. Ancak șirketin hissedarlarının büyük bir kısmının bu hisseleri sarraflardan borç alarak satın aldıkları bir gerçektir. Mustafa Reșid Pașa 20 hisse almak için ödediği 600 Osmanlı Lirasını da Banker Camondo'dan almıștır (Kazgan, 2014: 54). Dikkati çeken diğer bir önemli nokta ise Șirketi Hususi Nizamnamesinde yabancı uyruklulara hisse senedi verilmesinin yasak olmasına rağmen Camondo'nun bu engele takılmamıș olmasıdır. Șirket-i Hayriye'nin tüzüğünde, hisse senedi sahibi olan kișilerin Osmanlı vatandașı olmasının özellikle belirtilmesi ve yabancıların her ne biçimde olursa olsun șirket hisselerini aldıkları tarihten itibaren 3 ay içinde Osmanlı tebaasına satma zorunluluğu ve çalıșanlarını dahi Osmanlı vatandașı olma zorunluluğu șirketin milli kalmasını sağlamak amacıyla yapılmıștır (Sırma, 2011: 9). Ancak șirketin kurulușu sırasında hisse senedi alımının teșviki için, artık Camondolar adına geleneksel hale gelmiș olan bir "istisna" ile Abraham Camondo'nun da hisse sahibi olmasının yolu açılmıștır (lpek, 2011 : 195).

Bașlıca kamu hizmeti haline gelen Șirket-i Hayriyye, $1851^{\prime}$ de 6 vapurla bașlayan ișletmecilik hayatına vapur sayısını 1864'te 16'ya, 1872'de 34'e, 1909'a gelindiğinde ise 36'ya çıkarmıștır. İstanbul'da hizmet veren diğer ulașım sistemlerinden farklı olarak deniz ulașımının yönetimi bir Osmanlı șirketi tarafından yönetiliyordu. Ancak bu dönemde bașlatılan bütün projelerde olduğu gibi, Batı teknolojisine bağımlılık söz konusuydu. Vapurların Ingiltere'de yapılması ve bakımları için İngiliz mühendisler istihdam edilmesi ekonomik açıdan bağımlılık derecesini arttırmıștır (Çelik, 1986: 71, 72).

Cumhuriyet'in ilan edilmesinden sonra, çoğu yabancı menșeili olan toplumun yararına olan ișletmeler, imkânlar dahilinde devlet tarafından satın alınmaya bașlanmıștır. Șirketin, 1 Temmuz 
1944 günü bütün vapurları, Hasköy'deki fabrikası ve çekek yerleri, tașınır, tașınmaz mal varlıklarıyla Münalakât Vekâleti tarafından satın alınmıștır. Vapurları ve mal varlığı Devlet Denizyolları İșletmesi Genel Müdürlüğü Șehir Hatları Müdürlüğüne devredilmiștir. 15 Ocak 1945 günü de 4517 sayılı yasayla Șirket-i Hayriye de facto olarak ortadan kaldırılmıștır (Naza, 1994: 184).

\section{b) Dersaadet Tramvay Șirketi Içcerisindeki Rolleri}

30 Ağustos 1869'daki Dersaadet'te Tramvay Tesis ve inșasıyla ilgili bir sözleșmeyle İstanbul'da yolcu ve eșya tașımacılığı amacıyla ray döșenerek hayvanların çektiği araba ișletmeciliği imtiyazı 40 yıl süre ile Konstantin Krepano Efendi'nin kurmuș olduğu Dersaadet Tramvay Șirketi adlı șirkete verilmiștir (Kayserilioğlu, 1994: 199).

Levantenlerin ${ }^{7}$, ekonomi-iș çerçevesinde ulașımın İstanbul'da sıkıntılı olması nedeniyle zorlukları dile getirmesi ve Osmanlı bașkentini küçük bir Avrupai tarzda düzenlemek istemeleri Dersaadet Tramvay Șirketi'nin kurulmasında büyük rol oynamıștır. Camondolar'ın da içinde yer aldığı hissedarlar ileride arttırılabilmek șartıla 400.000 Osmanlı Lirasından ibaret olan sermaye her biri 20 Osmanlı Lirası olarak 20.000 hisseye bölünmüștür. Kurucular șirketteki sermaye paylarının karșılığı kadar hisse sahibi olabileceklerdir. Illk önce verilen geçici hisselerin asıl hisseye dönüștürülmesi amacıyla her hisse için ayrıca 5 'er Lira daha ödenecektir. Illk 5 yıl için tüm kurucu hissedarlar șirketin idare meclisini olușturacak, daha sonra yine hissedarlar arasından 6 kiși olarak seçilen idare meclisi üyeleri 3 yılda bir değiștirilecektir. İdare meclisi üyelerinin her biri 15 gün içinde 100 hisseyi șirket kasasına

7 Yorulmaz'a göre Levanten "Tarihsel süreç içerisinde özellikle Akdeniz ticaretinin parlak gelecek vadetmeye bașladığı dönemlerden itibaren ticaretin bulașıcı sihrine kapılıp gelen ve Osmanlı bașta olmak üzere, Doğu Akdeniz ülkelerine yerleșen değișik Avrupa ulus ve topluluklarından (Venedik, Cenevizli, İtalyan, İngiliz, Fransız, Hollandalı vs.) kimselerin zamanla birbirleriyle ve bazı yerel unsurlarla kaynașmaları, karıșmaları sonucunda farklı ölçülerde, değișken, sosyo-kültürel yapılarıyla ilginç bir çeșitleme ortaya koyan ama o ölçüde baskın yerel kültüre kapalı ve seçkin kalmaya çalıșan bir zümredir (Yorulmaz, 1995: 136). Türk Dil Kurumu ise Levanten'i "Özellikle Tanzimat'ı takip eden süreçte büyük liman șehirlerinde yoğunlașan ve ticaretle uğrașan Hıristiyanlara verilen ad" olarak tanımlamaktadır (TDK, 2017). 
verecektir. Camondolar'ın șirket içindeki payları bilinememekle birlikte sürecin İstanbul'dan ayrıldıkları bir döneme denk gelmesine rağmen hala ilișkilerini sürdürdükleri anlașılmaktadır (Ijpek, 2011: 198).

1869, 1881 ve 1907 yıllarında çıkan nizamnameler, sistemin gelișmesi ve kullanıșlılığı açısından temel bilgiler sunmaktadır. Batılılașma çabalarında yine Galata yakasına öncelik verilmesinin nedeni nüfus yoğunluğunun dikkate alınmasıdır. Kentin büyümesinin yönelimi ve seçkin nüfusa hizmet götürme isteği bir kez daha yatırımlarda belirleyici olmuștur. Yeni ulașım sisteminin İstanbul'un kent imajı üzerine belirgin bir çağdașlaștırıcı etkisi olmuștur (Çelik, 1986: 77,78).

\subsubsection{Diğer Bankerlerle ilișkileri}

İstanbul'da yașadıkları dönemde onlar kadar öne çıkan bașka bir Yahudi banker ailenin izine rastlamak mümkün değildir. Yüzyılın bașlarında öne çıkan zengin Yahudi aileler, ikinci yarısından itibaren yerlerini Rum ve Ermeni bankerlere bırakmıșlardır. Bu nedenle Camondolar'ın Osmanlı İmparatorluğu içinde birlikte iș yaptıkları ve ilișkide bulundukları bankerlere bakıldığında Yahudi isimlere pek rastlanmamaktadır.

Camondolar'ın Osmanlı İmparatorluğu içerisinde ilișkide bulunduğu bankerler çoğunlukla Rum bankerlerden olușmaktadır. Camondo, Todoraki Baltacı ile -her ne kadar bașarılı olamasa da- 1853 yılında bir banka kurma girișiminde bulunmuș, George Zarifi, Aristidi Baltacı ve Tubini bankerlerle Șirket-i Maliye'yi kurmuștur. 1864'de kurulan ve çok büyük bir girișim olan Șirket-i Umumiye'de Baltacı Aristidi, Mısırlıoğlu Bogos, Estefan, Zafiropoulo, George Zarifi ve Hristaki Zoğrafos'la birlikte sermaye ortaklığı yapmıștır. Austro Türk Bankası içinde, Hristaki, Zarifi, Kostaki ve Karapano isimleri ile beraber yer almıștır. Dersaadet Tramvay Șirketi içindeki ortakları da değișmemiștir: Hristaki Zoğrafos, Mösyö Zarifi ve Konstantin Karapano. Galata'nın ünlü bankerlerinin birlikteliği sadece kurulan șirketler veya bankalar içinde olmamıș, Osmanlı İmparatorluğu ile sık sık yapılan istikraz anlașmalarında da birlikte yer almıșlardır. Özellikle büyük tutarların sağlanmasın- 
da bu bankerler grubu beraber hareket etmișlerdir (lipek, 2011: 262).

Camondo Ailesi'nin Paris'e yerleșmesi ve dünya piyasası$\mathrm{nı}$ elinde bulunduran bankerlerle sıkı ilișkiler kurması, finansal entegre sürecini hızlandırmıș ve Paris'te saygın bir konuma ulașmıșlardır. Nitekim İstanbul'da yașadıkları sürece büyük ölçüde İstanbul piyasası ile sınırlı kalan Camondolar, Avrupa ve dünya piyasasına açılabilmek için onlarla yan yana olmaları gerektiğini anlamıșlardır. Onlar gibi Avrupa'da yașamalılar, aynı aristokrat çevreyi paylașmalılar, aynı zevklere sahip olmalılardır. Bu düșünceden hareketle İstanbul'un "șarklı" havasından çıkıp gerçek bir Avrupalı olmak adına Paris'te yerleșmek için Monceau Sokağı'nı seçmeleri bir tesadüf değildir. Baron Maurice de Rothschild, MısırIı Yahudi banker Cattauiler gibi Paris'in pek çok soylu ve yüksek sosyete ailelerinin, sanayici ve bankerlerinin yașadıkları bu sokak Camondolar'a yeni bir kimlik kazandırmak amacıyla seçilmiș ve bașarılı olmușlardır (Șeni ve Tarnec, 2010: 107).

\section{Sonuç}

Osmanlı İmparatorluğu'nda 1699'da imzalanan Karlofça Antlașması sonucu yașanılan toprak kayıpları, devletin bașta ekonomi olmak üzere hemen her alanda gerileme sürecine girmesine neden olmuștur. Osmanlı iktisat tarihinde, Sultan Abdülmecid Dönemi'nde, Mustafa Reșid Pașa'nın öncülüğünde İngilizlerle imzalanmıș olan 1838 tarihli Baltalimanı Ticaret Antlașması, OsmanIı maliyesi açısından doğurmuș olduğu olumsuz sonuçlarla, XIX. yüzyılın bütünü ile XX. yüzyıl bașlarına damga vuran en önemli gelișmelerden biri olmuștur. Söz konusu antlașma, Osmanlı yerli sanayi büyük oranda çökmesine ve ülke ekonomisinin Batılı emperyalist güçlerin etkisine açık hale gelmesine neden olmuștur. Bu antlașmayı takip eden süreçte İmparatorluk, Batılılașma hareketlerinin daha disiplinli ve görünür hale getirildiği Tanzimat Fermanı'nı 1839'da ilan etmiștir. Söz konusu fermanla askeri, ekonomik, eğitimsel, hukuksal vd. birçok farklı alanlarda değișim ve dönüșümün yașanacağı bir döneme girilmiștir. Mali alandaki reformları da kapsayan tüm bu iyi niyetli girișimlere rağmen, İmparatorluğun 
Kırım Savașı'nı sürdürmekte olduğu bir dönemde (1853-1856), 1854 'te yapmıș olduğu ilk istikraz (dıș borçlanma), mali yapının yeni ve daha kapsamlı sorunlarla karșı karșıya kalması sonucunu doğurmuștur. Sultan Abdülmecid Dönemi'nde açılmıș olan bu ilk borçlanma yolunun, sonrasında gelen diğer padișahlar tarafından da benimsendiği ve ardı ardına yapılan yeni borçlanmalarla Osmanlı maliyesinin bu durumu neredeyse bir "gelenek" haline getirmiș olduğu görülmektedir.

XIX. yüzyılda Osmanlı ekonomik sisteminin içerisinde bulunduğu olumsuz tablonun, bu yüzyılın özellikle ikinci yarısında, bașkent İstanbul'da Galata piyasasında iș yapan ve "Galata Bankerleri" olarak adlandırılan bir "sınıfın" da ortaya çıkmasına neden olduğu görülmektedir. Galata Bankerlerinin temel ișlevinin, Batı Avrupa'da gerçekleșen Sanayi Devrimi sonrasında, Osmanlı İmparatorluğu ile Batı sermaye çevreleri arasındaki ilișkiyi sağlamak olduğu söylenebilir. Söz konusu bu "banker sınffı", özellikle Osmanlı devlet adamlarıyla yakın ilișkiler kurarak, devlet nezdinde büyük kazançlar sağlamıștır. Önceleri salt Saray çevresi ve yüksek bürokrasi kesimi ile sınırlı olan ticari ilișkilerinin zaman içerisinde genișlemesi, bu sınıfın daha zenginleșerek kredibilite oranlarının yükselmesinin yolunu açmıșıır. Çoğunluğu Rum, Ermeni ve Yahudi tebaanın mensuplarından olușan bu "banker sınıfı", Osmanlı İmparatorluğu'nda modern bankacılığın kurulușuna kadar devletin iç borç sorununa o günün deyimiyle "idare-i maslahatçı" yani günü kurtaran geçici çözümler üretmeye çalıșmıștır. Bu geçici çözümler mali yapıyı hızla açmaza sürüklemiș̦tir. Bu Galata Bankerlerinin önde gelenleri arasında Camondolar, Baltazziler, George Tubini, Lorando, Bernard Corpi, Zanni Stefanovich, Shilizzi, Glavani, Raoul Crespin, Eustache Evyenidis, Fernandez, George Zarifi, Mavrokordato, Yorgo Zafiropula, Christaki Zografos, Jacques Alléon, Mısırlığlu Bogos Bey ve Köçeoğlu Agop isimleri sayılabilir. Söz konusu "banker sınıfı", 1908'de ilan edilmiș olan II. Meșrutiyet'e kadar, özellikle bașkent İstanbul'da faaliyetlerini etkin olarak sürdürmüșlerdir. II. Meșrutiyet yönetiminin her alana getirmiș olduğu milliyetçi yaklașımlardan Galata Bankerlerinin de etkilenmiș olduğu ve güçlerinin bu dönemde nispeten zayıflamıș olduğu söylenebilir. 
Calıșmamızın ana konusunu teșkil eden Camondo Ailesi'nin, siyasi, askeri ve ekonomik alanda birçok önemli sonuç doğuran ve Batılılașma hareketlerinin ilerlemesinin önünü açan en önemli gelișme durumundaki 1826'da II. Mahmut Dönemi'nde gerçekleștirilen Yeniçeri Ocağı'nın ortadan kaldırılması olayının Yahudi cemaatini de etkilediği ve dönüștürdüğü bir ortamda varlığını duyurmaya bașladığını söylemek mümkündür. Daha önce değinmiș olduğumuz, Osmanlı İmparatorluğu'nda XIX. yüzyılın önemli siyasi gelișmelerinden olan Tanzimat ve Islahat Fermanlarının yarattığı süreçte en çok gayrimüslimleri ilgilendiren bu reform hareketlerinden Yahudi cemaati ve özel anlamda da Camondolar büyük finans destekleri sağlamıștır. Söz konusu dönemde büyük bir nüfuz elde eden Camondo Ailesi hem ekonomik hem de siyasal ilișkiler yönünden güçlenmiștir. Osmanlı devlet adamları ve bürokratlarıyla yakın ilișkiler içinde olduğu bilinen ailenin, bu ilișkiyi temelde iki șekilde sürdürmekte olduğu görülmektedir. Bunlardan ilki Camondo Bankası ve devlet arasındaki resmi ekonomik ilișkiler, ikincisi de sarraf veya banker kimliğiyle Camondolar'ın bürokratlarla kișisel olarak kurdukları ilișkiler șeklinde kendini göstermektedir. Camondolar'ın devlet adamları ve bürokratlarla özel ilișkileri sonucunda geliștirdikleri sermayeleri, Osmanlı İmparatorluğu'nda kurulacak olan birçok ișletmenin finansmanın sağlanmasının da önünü açmıșıır. Bu durumu, ailenin imparatorluk için olumlu katkılarının da olmuș olduğu șeklinde değerlendirmek mümkündür.

Aile, özellikle Kırım Savașı sırasında savunma gereksinimleri ve sonrasında vergiler, gümrükler ve tekeller garantisiyle Osmanlı İmparatorluğu'nun bankerliğini yaparak daha da zenginleșmiștir. Osmanlı İmparatorluğu ile ilk iktisadi ilișkilerini bankacılık alanındaki faaliyetleriyle bașlatmıș olan Camondolar'ın, daha sonra bu faaliyet alanını ulașım sektörü gibi farklı alanlara da yaydıkları görülmektedir. 1815 yılında Abraham Camondo ve ağabeyi Isaac Camondo tarafından kurulan Isaac Camondo ve Șürekası Bankası Osmanlı'nın 1830'lardan itibaren birçok finansman ihtiyacını karșılamıș, aynı zamanda Avrupa merkezli bankalardan alınan kredi ve borçlanmalarda da etkin bir rol oynamıștır. Yeni bankaların ve bu arada Osmanlı Bankası'nın kurulması ile Banka, eski itibarını kaybetmeye bașlayarak yerlerini Ermeni-Rum bankerlere 
bırakmıșlardır. Osmanlı'daki bu girișimden sonra finans ve bankacılık alanında Șirket-i Maliyye, Șirket-i Umumiyye-i Osmani ve Austro-Türk Bankası kurulmuș ancak, bu kurumlar gerek kendilerinden beklenilen görevleri yerine getiremediklerinden gerek rekabet yarıșında geri kalmaları gerekse spekülasyon krizleri sonucu kısa süre içinde faaliyetlerine son vermek zorunda kalmıșlardır.

Finans alanından bașka, bașkent İstanbul'da birbirinden farklı sektörlerde faaliyette bulunmușlardır. Dersaadet Su Șirketi, Meriç Nehri Vapur İșletmeciliği, Belediye Hizmetleri ve Ulașım sektörü içinde yer aldıkları ortaklıklardandır. Aile, Osmanlı mali sisteminin ve ticaret kanunlarının olușturulmasında da çeșitli roller üstlenmiștir.

1860'lı yıllarda bașkent İstanbul'da ortaya çıkarak piyasada etkili olmaya bașlayan Rum Bankerlerin kurmuș oldukları yeni banka ve șirketler, Camondolar'ın yeni bir strateji belirlemesine neden olmuștur. Aile, dönemin en önemli finans merkezlerinden biri durumundaki Paris'e yerleșip; Avrupa ve Paris'in ünlü bankerleriyle birlikte çalıșarak, yerlerini almaya bașlayan Rum bankerlerle rekabet edebilmeyi hedeflemiștir. Camondo Ailesi'nin bu doğrultuda 1869 yılında Paris'e göç etme kararı almıș olduğu görülmektedir. Ancak Camondolar'ın benimsemiș oldukları strateji, ilerleyen süreçte İstanbul aleyhine bozulmaya bașlamıștır. Aile bu doğrultuda 1919 'da İstanbul'da bulunan șirketteki tüm menfaatlerinin ve gayrimenkullerinin tasfiyesi ile bağlantılarını kesmek yoluna bașvurmuștur. Ailenin, dönemin bașkenti İstanbul'da yaptırmıș olduğu hanlar, evler, apartmanlar, tașınmaz kültür varlıkları olarak günümüz İstanbul'unda da Camondolar'ın bugüne kalan izleri olarak görülmekte ve ailenin varlığını bugün de anımsatmaktadırlar. 


\section{KAYNAKLAR}

Akar, Ș.K. (2001), Osmanlı Devleti'nde Kısa ve Uzun Vadeli İç Borçlanmanın Gelișimi. İstanbul Üniversitesi İktisat Fakültesi Mecmuası. 51, 2.

Akyıldız, A. (2003), Para Pul Oldu Osmanlı'da Kağıt Para, Maliye ve Toplum. 1. Baskı, İstanbul: Illetișim Yayınları.

Al, H., Akar, Ș. K. ve Bayraktar, K. (2014), Osmanlı Finans Sisteminde Modernleșme 1: Devlet-i Aliyye-i Osmaniyye'de Merkez Bankası Arayıșları, Türkiye Cumhuriyet Merkez Bankası.

Anonim (1994), Su. Dünden Bugüne İstanbul Ansiklopedisi, 7, 48.

Anonim (2009), Dersaadet Ticaret Odası 1882-1923, İstanbul: İstanbul Ticaret Odası.

Assauline, P. (1998), Camondoların Sonuncus. İstanbul: Can Yayınları.

Avcı, M. (1994), Tercümanı Hakikat. Dünden Bugüne İstanbul Ansiklopedisi. 7, 253.

Aydın, V. (2002). Osmanlı Maliyesinde Bir İç Borçlanma Örneği Olarak Esham Uygulaması. Türkler Ansiklopedisi. 14, 605-613.

Bağıș, A. İ. (1983), Osmanlı Ticaretinde Gayri Müslimler: Kapitülasyonlar-Beratı Tüccarlar Avrupa ve Hayriye Tüccarları (1750-1839). Ankara.

Bayraktar, K. (2002), Osmanlı Bankası'nın Kurulușu, Cumhuriyet Üniversitesi i.i..B.F. Dergisi, 3(2), 71-88.

Buluș, A. (2010), Vergi Toplamanın Özerkleștirilmesinin Vergi Toplamanın Etkinliğine Katkısı: iltızam Sistemi ile Bir Mukayese. Kocaeli Üniversitesi Sosyal Bilimler Enstitüsü Dergisi. 19, 81-82.

Çelebi, B. (1994), İstanbul Su ve Kanalizasyon İdaresi (ISKI). Dünden Bugüne İstanbul Ansiklopedisi. 4, 234.

Çelebi, M. E. (2011), Galata ve Pera'da Otel Yapılarının Gelișimi (18401914). Sigma 3, 300-307.

Çelik, Z. (1986), 19. Yüzyılda Osmanlı Bașkenti Değișen İstanbul. İstanbul: Tarih Vakfı Yurt Yayınları.

Çetin, C. (2009), Baltazzi Ailesinin İktisadi Faaliyetleri ve Osmanlı Maliyesi İle ilișkileri. (Yayımlanmamıș Doktora Tezi). Marmara Üniversitesi Sosyal Bilimler Enstitüsü.

Demirkaya, G. (2010), İstanbul Beyoğlu'nda 19. Yüzyılda Banker Camondo Yapıları ve Adahan'ın Özellikleri. Yeniden Kullanım Önerisi. (Yayımlanmamıș Yüksek Lisans Tezi). İstanbul: Yıldız Teknik Üniversitesi Fen Bilimleri Enstitüsü. 
Erdem, E. (2006), Osmanlı Para Sistemi ve Tağșiș Politikası: Dönemsel Bir Ana-

liz. Türkiye Bankalar Birliği Bankacılar Dergisi. 56, 10.

Erdoğan, S. (1993), Türkiye'de Bankacılığın Tarihsel Gelișimi, Dicle Üniversitesi Hukuk Fakültesi dergisi, 6, 483-496.

Genç, M. (1995), Esham. Türkiye Diyanet Vakfı İslam Ansiklopedisi 11, 377.

Güleryüz, N. (1994), Kamondo, Avram. Dünden Bugüne İstanbul Ansiklopedisi. 4: 404.

Hulkiender, M. (2003), Bir Galata Bankerinin Portresi: George Zarifi (18061884). İstanbul: Osmanlı Bankası Arșiv ve Araștırma Merkezi Yayınları.

İpek, N. (201 1), Selanik ve İstanbul'da Seçkin Yahudi Bankerler. (Yayımlanmamıș Doktora Tezi). İstanbul: İstanbul Üniversitesi Sosyal Bilimler Enstitüsü.

Kayserilioğlu, R. S. (1998), Dersaadet'ten İstanbul'a Tramvay. İstanbul: I.E.T.T Yayınları.

Kazgan, H. (1995), Osmanlıda Avrupa Finans Kapitali. İstanbul: Yapı Kredi Yayınları.

Kazgan, H. (2014), Galata Bankerleri. İstanbul: Tarihçi Kitabevi.

Kıray, E. (1995), Osmanlı'da Ekonomik Yapı ve Dıș Borçlar. İstanbul: İletișim Yayınları.

Manav, N. (2009). Devlet-Banker Illișkileri Çerçevesinde Baltazzi Ailesi. (Yayımlanmamıș Yüksek Lisans Tezi). Marmara Üniversitesi Türkiye Araștırmaları Enstitüsü.

Naza, E. (1994). Șirket-i Hayriyye. Dünden Bugüne İstanbul Ansiklopedisi. 7, 181-184.

Oğlakçı, M. (2007), Galata Bankerlerinin Osmanlı Devlet Maliyesi Sistemine Etkileri: Baltazzi (Baltacı) Ailesi Örneği. (Yayımlanmamıș Yüksek Lisans Tezi). Afyonkarahisar Üniversitesi Sosyal Bilimler Enstitüsü.

Ortaylı, İ. (1987), İmparatorluğun En Uzun Yüzyılı. İstanbul: Hil Yayın.

Özdemir, B. (2009), 1854-1914 Borçlanmaları Galata Bankerleri ve Osmanlı Bankası Düyun-u Umumiye İdaresi Türkiye Cumhuriyeti'nin Kabul Ettiği Osmanlı Devlet Borçları. Ankara: Ankara Ticaret Odası Yayını.

Özdemir, B. (2009), Osmanlı Devleti Dıș Borçları. Ankara: Ankara Ticaret Odası Yayınları.

Pamuk, Ș. (2014). Osmanlı Ekonomisi ve Kurumları. İstanbul: Türkiye İș Bankası Kültür Yayınları.

Sakaoğlu, N. (1985), Tanzimat'tan Cumhuriyet'e Tarih Sözlüğü. İstanbul: İletișim Yayınları. 
Seyitdanlığlu, M. (2010), Tanzimat Döneminde Modern Belediyeciliğin Doğușu. İstanbul: İș Bankası Kültür Yayınları.

Silier, O. (1975), 1920'lerde Türkiye'de Milli Bankacılı̆̆ın Genel Görünümü, Türkiye İktisat Tarihi Semineri Metinler/ Tartıșmalar 1973, Ed. Osman Oktar, Hacettepe Matbaacilık, Ankara.

Sunay, C. (2002), Belediyeciliğin Doğuș Sürecinde Osmanlı. Kocaeli Üniversitesi Sosyal Bilimler Enstitüsü Dergisi. 3, 113-133.

Șeni, N. (2008), Seni Unutursam İstanbul... İstanbul: Kitap Yayınevi.

Șeni, N. ve Tarnec, S.L. (2010). Camondolar Bir Hanedanın Çöküșü. İstanbul: Kitap Yayınevi.

Tabakoğlu, A. (2014), Türkiye İktisat Tarihi. İstanbul: Dergah Yayınları.

TDK (2017), Levanten, http://www.tdk.gov.tr/ (12.03.2017).

Timur, T. (1990), Bir Osmanlı Banker Ailesi Kamondo'lar. Tarih ve Toplum. 64: (74), 56.

Toprak, Z. (1993), Belediye. Dünden Bugüne İstanbul Ansiklopedisi. 2, 138140.

Tugay, E.C.. ve Tugay, M.S. (2009), Kamondo Han. İstanbul: Illke Basın Yayın.

Yorulmaz, Ș. (1995), "Tarih Sürecinde Bir Zümre: Levantenler.» Dokuz Eylül Üniversitesi Çağdaș Türkiye Tarihi Araștırmaları Dergisi, 2:129-136. 


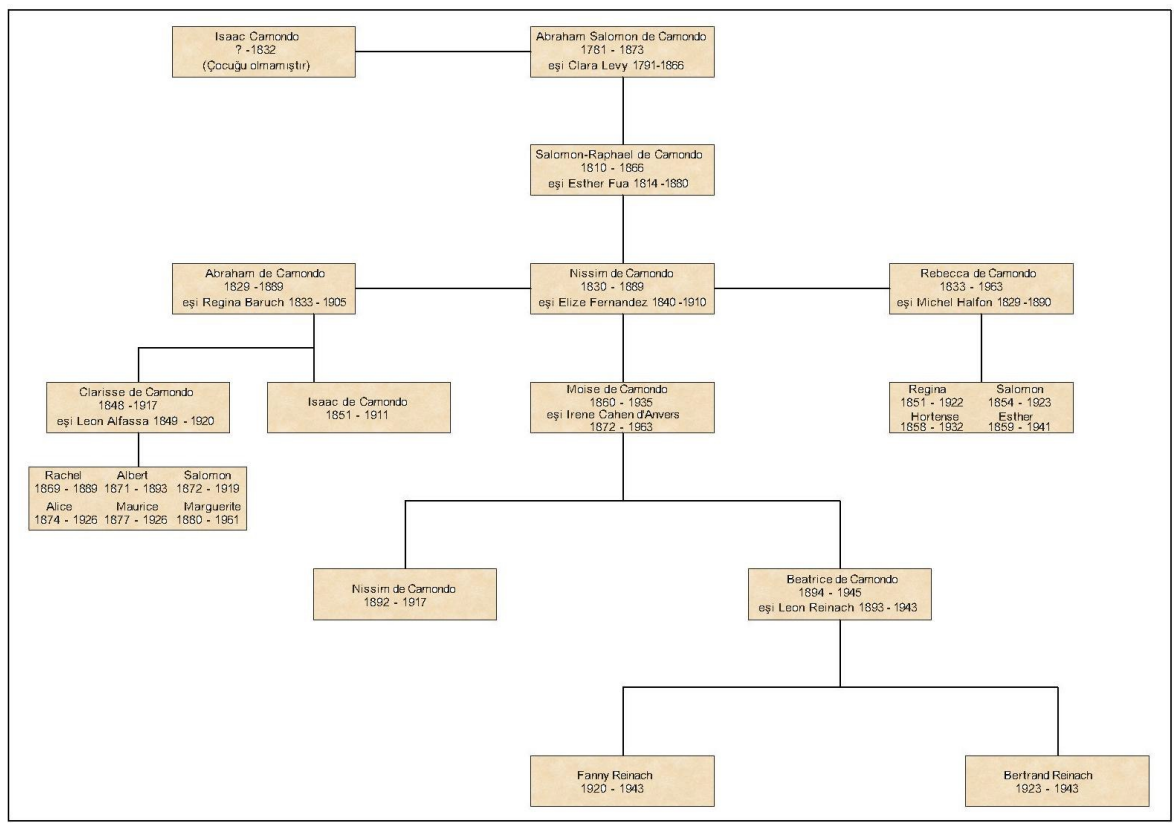

Kaynak: (Șeni ve Tarnec, 2010: 292). 